University of Michigan Law School University of Michigan Law School Scholarship Repository

1979

\title{
Accelerated Depreciation-Tax Expenditure or Proper Allowance for Measuring Net Income?
}

Douglas A. Kahn

University of Michigan Law School, dougkahn@umich.edu

Available at: https://repository.law.umich.edu/articles/313

Follow this and additional works at: https://repository.law.umich.edu/articles

Part of the Legislation Commons, Taxation-Federal Commons, and the Tax Law Commons

\section{Recommended Citation}

Kahn, Douglas A. "Accelerated Depreciation—Tax Expenditure or Proper Allowance for Measuring Net Income?" Mich. L. Rev. 78 (1979): 1-58.

This Article is brought to you for free and open access by the Faculty Scholarship at University of Michigan Law School Scholarship Repository. It has been accepted for inclusion in Articles by an authorized administrator of University of Michigan Law School Scholarship Repository. For more information, please contact mlaw.repository@umich.edu. 


\title{
ACCELERATED DEPRECIATION - TAX EXPENDITURE OR PROPER ALLOWANCE FOR MEASURING NET INCOME?
}

\author{
Douglas A. Kahn*†
}

\section{INTRODUCTION}

Since the 1950s, it has become fashionable to attack various provisions of the Internal Revenue Code by calling them "subsidies" rather than "proper" means of measuring taxable income." These "subsidies" through Code provisions have come to be referred to as "tax expenditures," a term coined by Professor Stanley Surrey in a speech he made as Assistant Secretary of the Treasury for Tax Policy on November 15, 1967.2 In that speech, Professor Surrey stated that our tax system often deliberately departs "from accepted concepts of net income," so that by granting exemptions, deductions, and credits that are not appropriate to an accurate determination of net income, the tax laws effectively provide what is usually accomplished by direct expenditures. In effect, the Code produces "an expenditure system described in tax language." 3 The two principal complaints against "tax expenditures" are that they are hidden within the tax system and so do not receive the careful scrutiny to which direct expenditures are subject ${ }^{4}$ and that they distort the proportionate burden imposed by our progressive tax system and thereby violate the principles of horizontal and vertical equity. ${ }^{5}$ Under Professor Surrey's guidance, in 1968 the Treasury Department developed a "Tax

* Professor of Law, University of Michigan. B.A. 1955, University of North Carolina; J.D. 1958, George Washington University - Ed.

$\dagger$ (c) Copyright 1980 Douglas A. Kahn. The author wishes to thank the following friends and colleagues who were kind enough to read a draft of this Article and to offer their criticisms and comments: Edwin L. Kahn, Professors William D. Andrews, Marvin A. Chirelstein, Mary Lou Fellows, Pamela Gann, Richard Lempert, Michael Rosenzweig, and Peter O. Steiner. Several other persons gave me their criticisms but I have omitted their names in the belief that they would prefer it that way.

1. See, e.g., Blum, The Effect of Special Provisions in the Income Tax on Taxpayer Morale, in Readings in Federal Taxation 41, 42 (1970).

2. See S. Surrey, Pathways to TAX Reform 3 (1973).

3. $I d$. at 3.

4. See id. at 1-4.

5. See Surrey, Tax Incentives as a Device for Implementing Government Policy: A Comparison With Direct Expenditures, 83 HARv. L. REv. 705, 720-23 (1970). Essentially, "horizontal equity" means that persons having equal incomes should pay an equal amount of taxes. "Ver- 
Expenditure Budget" that purported to identify the tax subsidies provided by the Code and to quantify the revenue cost of each subsidy. ${ }^{6}$

For some years, the Tax Expenditure Budgets prepared by various arms of the government have listed as a tax subsidy the amount by which the accelerated depreciation deductions taken on buildings exceed the amount of depreciation that would have been allowable under the straight line method of depreciation. ${ }^{7}$ A recent budget prepared by Treasury for individual taxpayers lists the excess of accelerated depreciation deductions over straight line as a tax subsidy that cost the federal fisc some $\$ 460,000,000$ in the year $1977 . .^{8}$ In addition, the "subsidy" for asset depreciation range (ADR), an election that permits a form of accelerated depreciation, ${ }^{9}$ was stated to be $\$ 100,000,000$. In a budget for fiscal year 1979 , the tax subsidy for accelerated depreciation of buildings for both corporations and individuals was stated to be $\$ 605,000,000$, and the tax subsidy for ADR was stated to be $\$ 2,775,000,000 .{ }^{10}$

Many tax commentators, government officials, and members of Congress have adopted the concept of a Tax Expenditure Budget since Professor Surrey introduced it in 1967. Indeed, the Congressional Budget and Impoundment Act of 1974 requires that Congress and its budget committees examine tax expenditures as part of overall Federal budgetary policy. ${ }^{11}$ In July 1979, the Comptroller Gen-

tical equity" means that persons having a disparate amount of income should pay disparate taxes in proportion to the progressive rate structure established by Congress.

6. See S. SURREY, supra note 2, at 4-14.

7. See id. at 8-9; Senate Comm. on the Budget, 94Th Cong., 2D Sess. Tax Expenditures, Compendium of Background Material on Individual Provisions 51 (1976) [hereinafter cited as TAX EXPENDITURES]. Accelerated depreciation methods for machinery and equipment (other than the asset depreciation range election) are not included in the Tax Expenditure Budget because it is assumed such items often decline in value more rapidly in early years than in later years. See TAX ExpEnditures, supra at 52.

8. Tables Prepared by Treasury Department for Chairman Edmund Muskie of Senate Budget Committee Showing Distribution of "Tax Expenditures" Benefits Among Individual Taxpayers by Income Categories, Dally TAX ReP., No. 29, J-20, J-21 (Feb. 10, 1978). Those tables have a separate item for the tax subsidy given as accelerated depreciation on rental housing $(\$ 320,000,000)$ and a separate item for the depreciation of other buildings in excess of straight line $(\$ 140,000,000)$. The Tax Expenditure Budgets typically distinguish rental housing from other buildings. For a list of budgets prepared by various arms of the government, see Surrey \& McDaniel, The Tax Expenditure Concept: Current Developments and Emerging Issues, 20 B.C. L. REv. 225, 231 n.12 (1979).

9. See note 57 infra and accompanying text.

10. Office of Management and Budget, Special Analysis, Budget of the United STATES GOVERNMENT 158-59 (1978).

11. Congressional Budget and Impoundment Control Act of 1974, Pub. L. No. 93-344, $\S \S 3(\mathrm{a})(3), 101(\mathrm{c})(5), 102(\mathrm{a})(2), 88$ Stat. 297. Section 601 of that Act (codified at 31 U.S.C. 11(e) (1976)) requires the President to include tax expenditures as an item in the budget that he submits to Congress. 
eral, who heads the General Accounting Office, urged Congress to include the Code's tax expenditures in proposed "sunset" legislation, so that they would expire after a stated period of time unless Congress took positive action to retain them. ${ }^{12}$

The tax expenditure concept rests on the belief that there is a "correct" definition of net income. Since the presumed purpose of a net income tax system is to require persons to bear governmental costs in proportion to their "ability to pay," the criteria used to measure net income should accurately reflect the differences in taxpayers' abilities to pay. A tax expenditure occurs when the Code excludes or deducts an item from gross income and the exclusion or deduction does not comport with the "correct" definition of net income. The original Treasury analysis stated that the tax expenditures listed in the budget covered "the major respects in which the current income tax bases deviate from widely accepted definitions of income and standards of business accounting and from the generally accepted structure of an income tax." 13 The Tax Expenditure Budget most nearly rests ${ }^{14}$ on the Haig-Simons definition of net income which defines personal income as "the algebraic sum of (1) the market value of rights exercised in consumption and (2) the change in the value of the store of property rights between the beginning and the end of the period in question." 15 In other words, income equals personal consumption plus accumulation of wealth over a stated period of time. In preparing the Tax Expenditure Budget, the Treasury Department does not adhere strictly to the Haig-Simons definition but rather treats it as an "outer limit" that helps identify the items to be included in the list of tax subsidies. ${ }^{16}$ While stressing that the HaigSimons definition is a useful analytical tool, the Treasury Department acknowledges that "it is not suitable for all purposes and would not, without modification, describe a satisfactory tax base."17

12. Dally TaX Rep. No. 135, at G-3 (July 12, 1979). See also H.R. 5858, 96th Cong., Ist Sess. (1979), discussed in DaILY TAX REP., No. 219, Nov. 9, 1979, at G-3, proposing that each congressional committee be required to perform "sunset review" every two years on all tax expenditures within its jurisdiction.

13. See S. SURREY, supra note 2, at 7, 12.

14. See id. at 12.

15. H.C. Simons, Personal Income Taxation 50 (1938). At 61-62, Simons discusses some refinements of the definition of personal income tax. See also Haig, The Concept of Income, in The Federal Income TAX 7 (R. Haig ed. 1921), reprinted in AMERICAN EcoNOMIC Association, Readings in the ECONOMics OF TAXation 54 (1959).

16. U.S. Dept. of the Treasury, Blueprints for Basic Tax Reform 22 (1977) [hereinafter cited as TREASURY BLUEPRINTS].

17. Treasury Blueprints, supra note 16, at 22-23. See S. SuRReY, supra note 2, at 1216; Surrey \& Hellmuth, The Tax Expenditure Budget - Reply to Professor Bittker, 22 NATL. TAX J. 528, 531 (1969). 
A number of items within the Haig-Simons definition of income (and within the definition generally employed by economists) are inappropriate in a tax system, and so the tax expenditure budgets do not treat the exclusion of such items from taxable income as a tax preference. Later, we will examine several important exclusions from taxable income that are necessary to a workable tax system, even though such items fall within the definition of income employed by many economists. The reason that such differences exist is that the "income" of a person is not measured in the same manner for all purposes. For example, in determining a business's income for tax purposes, the assets used in the business are depreciated on the basis of their historical cost even if they will soon have to be replaced at a much greater cost. On the other hand, a potential buyer, considering whether the annual income stream from the business justifies the asking price, will surely calculate depreciation on the basis of the assets' replacement cost. That calculation will produce the net income that will be available after the existing assets are replaced. An economist generally determines the cost of using an item in a business as the value of the most profitable alternative use to which the asset could be put, and a calculation of income on that method is useful to the owner of the business in determining whether it is advantageous to continue to operate that business or to shift to another activity; but such a definition would be an inappropriate means of measuring taxable income.

Professor Bittker has voiced a number of objections to the Tax Expenditure Budget in his debates with Professors Surrey and Hellmuth and others. ${ }^{18}$ In general, a consideration of the strengths and fallacies of the Tax Expenditure Budget concept is outside the scope of this Article, but one drawback of the Budget concept does relate to the subject at hand. The promulgation of a list of "tax subsidies" suggests that there is a widely accepted view of the correct means of measuring income. While Professor Surrey acknowledges that "the precise contours of the dividing line" are uncertain, he notes that the tax expenditure concept rests on "a normative model for an income tax structure - what receipts should be included and what expenses allowed to obtain the proper measure of net income for an income tax." 19 Even if the Haig-Simons definition were

18. See Bittker, $A$ "Comprehensive Tax Base" as a Goal of Income Tax Reform, 80 HARv. L. REv. 925 (1967); Bittker, Accounting for Federal "Tax Subsidies" in the National Budget, 22 Natl. TAX J. 244 (1969); Bittker, The Tax Expenditure Budget - A Reply to Professors Surrey and Hellmuth, 22 NATL. TAX. J. 538 (1969); Bittker, Income Tax "Loopholes" and Political Rhetoric, 71 Mich. L. REv. 1099 (1973).

19. Surrey, Tax Incentives - Conceptual Criteria for Identification and Comparison with 
adopted, it is not free of ambiguity and its application to many specific circumstances rests on value judgments over which many persons will differ. ${ }^{20}$ Once the Treasury Department lists an item as a tax expenditure, there is a substantial risk that congressional debate on that item will be limited to the merits of subsidizing particular behavior and will not investigate whether it offers a proper measure of net income.

Reasonable men may well disagree about whether an item of deduction or exemption is a proper allowance to reflect a taxpayer's net income. For example, Professor Andrews, while largely adopting the Haig-Simons definition, disputed the inclusion in the Tax Expenditure Budget of the deductions allowed for medical expenses and charitable contributions. ${ }^{21}$ Professor Surrey countered that Professor Andrew's criticism does not rest on a proper construction of the Haig-Simons definition but rather is premised on a model of income that differs from the one "traditionally used by economists in structuring an income tax."22 It is surprising that Professor Surrey relied on the economists' view of income, since only a few pages earlier in his book he called that view too "novel" to be adopted in its entirety in the Tax Expenditure Budget and approved of the Treasury Department's reliance on "widely accepted definitions of income" and the "generally accepted structure of an income tax."23 Regardless of whether Professor Surrey is correct, his exchange with Professor Andrews focuses attention on another important aspect of the Tax Expenditure Budget. Whether personal expenses such as medical fees, theft losses, and casualty losses are proper deductions depends upon the extent to which one believes that a person's taxable income should be measured by the annual accretion to his distributable or disposable wealth as contrasted to accretions to his wealth in general. ${ }^{24} \mathrm{I}$ believe (and some others do not) that deductions for such items as theft and casualty losses are proper allowances to reflect the taxpayer's true "ability to pay" (i.e., his ability to share the costs of

Direct Government Expenditures, in TAX INCENTIVEs 5 (1971), quoted in Surrey \& Hellmuth, supra note 17 , at 531.

20. See Bittker, Accounting for Federal "Tax Subsidies" in the National Budget, 22 NATL. TAX J. 244, 260 (1969). (1972).

21. See Andrews, Personal Deductions in an Ideal Income Tax, 86 HARv. L. Rev. 309

22. S. SurReY, supra note 2, at 20. See also Kelman, Personal Deductions Revisited: Why They Fit Poorly in an "Ideal" Income Tax and Why They Fit Worse in a Far from Ideal World, 31 STAN. L. REV. 831 (1979).

23. See S. SURREY, supra note 2 , at 18.

24. Professors Surrey and McDaniel maintain that "disposable income" is not a proper measure of taxable income. Surrey \& McDaniel, supra note 8, at $260 \mathrm{n} .88$. 
government). The determination of the breadth or narrowness of the deductions that should be allowed to measure net income properly rests on an individual's value judgments. ${ }^{25}$ Even if Andrews's model of an ideal tax differs from the Haig-Simons model and from the traditional view of economists, it may still be a better measure of "ability to pay" than the traditional model.

The Haig-Simons definition of income is an algebraic sum that includes "consumption." Professor Andrews construes "consumption" more narrowly than Professor Surrey and probably more narrowly than did Professor Simons. The question of which is the better construction rests on value judgments whose selection should be subject to debate in Congress and in the tax literature. That debate should not be stifled by the Treasury Department's formal designation of items as tax preferences on the latent premise that it has discovered the true and correct "model" of net income. While the Treasury Department does modify the items listed in its Budget from time to time, the Budget perpetuates the value judgments held by Treasury officials and cloaks them with an unwarranted indisputability.

Since the Treasury Department acknowledges that the HaigSimons definition does not describe a satisfactory tax base for a workable tax system, and since the Treasury Department does not adhere to the Haig-Simons definition in preparing the Tax Expenditure Budget, how does it determine which departures from the HaigSimons model are tax expenditures and which are not? The Treasury analysis states that it relies on "widely accepted definitions of income" and the "generally accepted structure of an income tax."26 Those standards do not inspire confidence in the validity of the Tax Expenditure Budget; they bear a distressing similarity to the familiar but virtually useless standard that income should be determined according to generally accepted accounting principles. ${ }^{27}$ Whatever the validity of the Tax Expenditure Budget, it has become a powerful political tool for the Treasury to focus congressional scrutiny on certain subjects and to narrow the scope of such scrutiny to the question of whether an included item is an appropriate subsidy.

25. See McIntyre, A Solution to the Problem of Defining a Tax Expenditure, (1980) (unpublished manuscript on file at Michigan Law Review).

26. S. SURREY, supra note 2, at 12, 18.

27. A statement by an accountant that he is reporting income according to generally accepted accounting principles is meaningful in that it represents that he complied with certain established standards. But, these standards are of no help in construing an instrument that directs that income is to be determined "according to generally accepted accounting practices," and that description is so vague as to have little significance. 
A number of items that are included within income under the Haig-Simons definition are excluded from the Tax Expenditure Budget because they are properly excluded from the tax base of an income tax system geared to an individual's ability to pay for government. For example, imputed income from services that a taxpayer performs for himself or from property (such as a residence) that he owns and uses for personal enjoyment is properly excluded from the income tax base even though such "income" increases the taxpayer's net worth. ${ }^{28}$ Among the exceptions to the Haig-Simons definition, two are especially relevant to this Article: the doctrine of realization and the cash receipts and disbursement method of accounting. ${ }^{29}$ The various Tax Expenditure Budgets treat both the doctrine of realization and the cash method as integral elements of our tax system. The cash method can be characterized merely as an application of the realization doctrine, but for analytical purposes it is useful to treat those two as separate exceptions to Haig-Simons.

The doctrine of realization provides that the appreciation or depreciation in value of an asset will not be included in or deducted from the income of the owner until the gain or loss is "severed" from the asset. Thus where $A$ owns a share of stock of the $\mathrm{X}$ Corporation, no portion of the earnings of $\mathrm{X}$ will be included in $A$ 's income, even if those earnings cause the value of $A$ 's share of X stock to increase, until they are severed from $A$ 's share of stock by a corporate distribution to $A$. Similarly, the appreciation in value of $A$ 's share of $\mathrm{X}$ stock will be included in $A$ 's income only when $A$ severs the appreciation of his capital (i.e., realizes it) by selling the stock for more than his basis. Thus, the unrealized appreciation of an asset is not included in the owner's gross income, and, conversely, the unrealized depreciation of an asset is not deductible from the owner's income. An early Supreme Court decision ${ }^{30}$ held that realization of gain was a constitutional requisite to including the gain in income. While it is

28. See S. SURReY, supra note 2, at 12-13.

29. In Pathways to TAX Reform Professor Surrey states, at 23, that in preparing the Tax Expenditure Budget "the Treasury analysis views the coexistence of the cash receipts and accrual accounting methods as a part of the structure of an income tax system." In Surrey \& McDaniel, supra note 8, at 229, the authors quote from an address by Professor Surrey as follows:

Since the Haig-Simons approach does not identify appropriate accounting techniques, resort in establishing a normal structure is made to widely accepted "standards of business accounting" used to determine income for financial reports. The application of these economic and accounting norms is then tempered by also referring to the "generally accepted structure of an income tax." This reference, it was pointed out, excluded as normiative the inclusion of unrealized appreciation in asset values . . . since in the United States, and largely elsewhere, these items are not commonly regarded as income for income tax purposes though they fall within the economic definition of income.

- 30. Eisner v. Macomber, 252 U.S. 189 (1920). 
no longer believed that realization is constitutionally required, the realization doctrine is good tax policy, and the doctrine is a basic element of our income tax system. Except in a few situations involving the attribution of income from certain types of foreign corporations to United States shareholders, ${ }^{31}$ income is not taxed until it is realized.

The realization doctrine is necessary both because measuring the appreciation or depreciation in value of a taxpayer's assets every year may be administratively difficult and because taxing unrealized appreciation may be grossly unfair. ${ }^{32}$ The value of an asset can change drastically in a short period of time, ${ }^{33}$ and so there is an arbitrariness to taxing a person on appreciation that existed at a given instant, where the value the day before or the day after was quite different. Where a taxpayer realizes a gain by severing it from an asset, he permanently captures that gain; but the transitory rises and dips in market price while a taxpayer holds an asset are not sufficiently significant or permanent to warrant taxing him on such "paper" wealth ${ }^{34}$ or to warrant granting him a deduction for such "paper" losses. The speculation involved in determining the value of many types of assets aggravates the problem. The price for which an owner can liquidate an asset often is substantially less than the theoretical market price: an owner typically cannot sell on a moment's notice, and actual offers frequently differ from an expert's speculation about the price that buyers will offer.

Taxing unrealized appreciation could also force a taxpayer to dispose of an asset in order to raise the funds needed to pay the taxes imposed on his paper gain. ${ }^{35}$ Unless the taxpayer has sufficient liquid capital available, he would have to sell something, either the appreciated asset or some other item. The current high rate of inflation would make such a tax system especially onerous. Consider, for example, the extraordinary increase in the price of housing that has taken place in recent years. Taxing a homeowner on such appreciation at progressive income tax rates could be ruinous, even with a

31. See, e.g., I.R.C. $\$ 551$ (attributing the undistributed foreign personal holding company income of a foreign personal holding company to its United States shareholders). See also I.R.C. $\S 951$.

32. See Treasury Blueprints, supra note 16, at 47. See also note 29 supra.

33. The "volatility and transient character of market prices of a common stock" are illustrated in the Appendix to Justice Powell's dissenting opinion in Ivan Allen Co. v. United States, 422 U.S. 617, 653-58 (1975).

34. The unreliability of market quotations of common stock as an indicator of the "true" or "realistic" value of such stock was discussed by Justice Powell in his dissenting opinion in Ivan Allen, 422 U.S. at 646-49.

35. See TREASURY BluePRINTS, supra note 16, at 47. 
capital gains deduction. Indeed, the imposition of increasing property taxes on such paper accretions of wealth apparently ignited the taxpayer "revolt" that fostered California's Proposition 13.

The doctrine of realization is an integral part of our tax system, and its desirability as a matter of tax policy is widely accepted. Significantly for this Article, not even the Tax Expenditure Budget includes the failure to tax unrealized appreciation as a tax preference or expenditure. Whether any other item of tax exclusion or deduction constitutes a tax preference depends upon whether it varies from normal tax practice, including the requirement of realization. Thus, if income is deferred because of the doctrine of realization, the deferral is not a tax subsidy but rather a concomitant of a necessary element of our tax system.

A second major exception to the Haig-Simons definition is the authorization for certain taxpayers to use the cash receipts and disbursements method of accounting (hereinafter referred to as the "cash method"). ${ }^{36}$ Most individual taxpayers and many entities use the cash method. On the other hand, many businesses use the "accrual method" of accounting. Under the accrual method, a taxpayer takes an item of income into account when his right to that item becomes fixed and the amount thereof can be determined with reasonable accuracy, even if he will not receive that income until some future date. ${ }^{37}$ Similarly, a taxpayer using the accrual method deducts an item of expense when he becomes unconditionally obligated for that expense and its amount can be determined with reasonable accuracy, even if he does not have to pay the item for some time.38 A businessman needs to know whether he is operating at a profit or a loss and he needs that information to be current so that he can locate problem areas and correct them before he becomes insolvent. The accrual method provides a more accurate picture of the current success or failure of a business activity than does the cash method. ${ }^{39}$

Under the cash method, income is reported only when the taxpayer actually or constructively receives cash or its equivalent. ${ }^{40}$ The taxpayer constructively receives income in a taxable year if he

36. See S. SURREY, supra note 2, at 23. Since the Haig-Simons approach does not specify the accounting techniques, the cash method arguably is not an exception to that approach. In any event, the Tax Expenditure Budgets do not treat the cash method as a tax preference.

37. Treas. Reg. \& 1.446-1(c)(1)(ii) (1957).

38. Id.

39. The tax laws often (but not always) adhere to established business accounting practices. Thus, the Code permits, and in certain cases requires, the use of accrual accounting. I.R.C. $\$ \$ 446,447$.

40. Treas. Reg. $\$ 1.446-1$ (c)(1)(i) (1957). 
can draw upon it at some time during the year and if there is no substantial restriction on his right to receive the income item during that year. ${ }^{41}$ The cash method defers recognition of income until the taxpayer actually or constructively receives payment. It is permitted principally because it measures taxable income in a way that the government may administer easily. Moreover, to require all taxpayers to do the bookkeeping and accounting necessary to report their income on the more sophisticated accrual method would impose too great an expense on most individuals. And, as with the doctrine of realization, it would impose a hardship on many individuals to require them to pay taxes on an accrued item of income that they will not actually receive in hand for several years. Although Congress has created several limited exceptions to its authorization of cash method reporting, ${ }^{42}$ the cash method is an integral part of our tax system.

Having expressed some skepticism about whether there is a sin-

41. Treas. Reg. § 1.451-2 (1964).

42. One exception is the deferral permitted the vendor of certain types of properties on an installment sale where the vendor elects to report the gain from that sale in installments. I.R.C. \& 453. (If installment reporting were not authorized, even a cash method vendor might have to recognize all of the gain from an installment sale in the year of sale since, for example, a secured promissory note of the purchaser may constitute the equivalent of cash and cause the vendor to realize an amount equal to the fair market value of that note.) Another exception is the treatment of original issue discount on a corporate bond or other corporate evidence of indebtedness as described below.

Where a corporation issues a bond at a discount (i.e., the price paid for the bond is less than the amount payable at maturity), the amount of discount represents additional interest on the bond. Since the early years of the income tax, a corporation which issues such a bond has been required to report the discount as an interest deduction ratably over the term of the bond. Treas. Reg. $\S \S 1.163-3$ (a) (1968); 1-163-4(a) (1971). In the Tax Reform Act of 1969, for the stated purpose of providing parallel treatment to bondholders and the corporate debtor, $S$. REP. No. 91-552, 91 st Cong., Ist Sess., 146-47 (1969), Congress amended § 1232 to require that any holder of a corporate bond, or other corporate evidence of debt, that was issued with original issue discount after May 27, 1969, report a proportionate part of the original issue discount as income each year. There are some exceptions to this requirement. It does not apply to bondholders of government bonds presumably because, as tax exempt entities, governments do not deduct a portion of the original issue discount each year, and so the bondholder need not be required to report such income in order to obtain parallel treatment.

If parallel treatment is indeed the reason for requiring the ratable recognition of original issue discount by a bondholder, it is a poor justification. Parallel treatment is not necessarily desirable, and where different parties to a transaction utilize different accounting methods, unparallel treatment often will occur and appears to be unobjectionable if the parties are unrelated. Transactions between related parties with different accounting methods might be undertaken for tax avoidance reasons, and perhaps special restrictions should be imposed on such transactions. For example, in $\$ 267$, Congress has imposed limitations on the deductibility of interest and losses incurred on transactions between certain related parties that do not apply to others.

Whatever the wisdom of requiring the pro-rata reporting of discount interest from corporate bonds, Congress has not expanded that exception to cash method reporting to other areas. Since the cash method is also an integral part of our tax system, an exclusion of an item from the income of a cash method taxpayer can constitute a tax "preference" only if the exclusion rests on some ground other than a deferral provided by the cash method itself. 
gle "true" definition of income, I should make clear that I do not consider the term meaningless. As noted above, ${ }^{43}$ income is a narrower concept for tax purposes than it is for purposes of economic theory, and income is a value-laden concept. In general, for tax purposes "income" refers to net income - gross receipts less certain deductions and set-offs. Fortunately, depreciation, which is the focus of this Article, is not a personal expense and is relatively free from the value judgments that adhere to questions of deductibility of personal expenses. ${ }^{44}$ Thus, almost all scholars agree that a person who expends money to acquire an asset that will produce income over a period of time should be allowed to recover the cost of his investment as an offset against the income earned from it. The controversy over depreciation has instead centered on the proper method of cost recovery, specifically the extent to which capital recovery may be "accelerated." With this Article, I hope to illuminate that controversy more clearly.

It will be easier to determine whether a specific method of cost recovery is proper for the measurement of taxable income after a brief review of the reasons for allowing recovery at all. As we shall see, no method of cost recovery is exclusively correct, but rather a range of methods are all conceptually defensible, although some may be appropriate more often than others. The proper allocation of cost depends upon estimates of such matters as: the useful life of an asset; the income stream to be produced by the asset; and salvage value. Frequently, these "estimates" are merely very rough guesses. It is unlikely that any one method of recovery will be the singly correct one when it must operate with such imprecise data. For that and other reasons, the tax law usually permits a taxpayer to elect any of several methods, so that he can tailor the method to fit more closely his particular circumstances. In determining whether a cost recovery method is appropriate for a particular circumstance, I shall often examine closely analogous circumstances where that method of cost recovery is accepted without challenge. Whether or not the method is the very best method available, it cannot be inappropriate unless it is inappropriate in the analogous circumstance or some meaningful distinction between the two circumstances can be found.

This Article studies the extent to which accelerated depreciation accurately reflects net income. It does so by reference to the traditional yardsticks against which we must scrutinize all cost recovery

43. See text following note 17 supra.

44. See text at note 24 supra. 
methods: the goal of measuring an individual's ability to pay the costs of government and the constraints accepted as essential to our tax system, including the doctrine of realization and the cash method of accounting. The current view, which appears to be held almost universally, is that accelerated depreciation is a tax subsidy; some commentators have suggested that even straight line depreciation offers an inappropriately large deduction in the early years of an item's use. $^{45}$ The popular analysis rests on two related premises:

1) the depreciation deduction for an asset should not exceed the difference between the taxpayer's basis in the asset at the beginning of the year and the asset's fair-market value at the end of the year, and

2) so-called "sinking fund depreciation" - the difference between the present value of an asset's projected income stream at the beginning of the year and the present value of the asset's projected income stream, taken at the end of the year - is the economically accurate measure of depreciation.

Those premises have been partially integrated into the Tax Expenditure Budget in that it lists the excess of accelerated depreciation on buildings over straight line and the additional depreciation obtained through asset depreciation range ${ }^{46}$ as a tax expenditure. The thesis of this Article is that some amount of accelerated depreciation (although not necessarily the full amount allowable under all of the provisions of the Code) is a proper deduction in determining net income and provides a more accurate statement of net income than straight line or decelerated depreciation methods. At the very least, accelerated depreciation provides a deduction that is no less appropriate than straight line or decelerated methods.

Finding a conceptual justification for accelerated depreciation has several important implications. First, the perspective shifts for challenges to even the most extreme forms of accelerated depreciation. Second, the Tax Expenditure Budgets overstate the amount of tax expenditure for accelerated depreciation and its very inclusion in the Budgets is questionable. Third, the current limitations on the availability of accelerated depreciation for buildings are unjustified and should be reconsidered. Fourth, Congress should repeal the inclusion in sections 57(a)(2) and (3) of the accelerated depreciation on buildings and certain other properties as tax preference items. Fifth, Congress should repeal the statutory prohibition against reducing a corporation's earnings and profits by the accelerated portion of a de-

45. See, e.g., M. Chirelstein, Federal Income Taxation \ 6.07, at 133-35 (2d ed. 1979); Surrey \& McDaniel, supra note 8, at 243 n.38.

46. See note 57 infra and accompanying text. 
preciation deduction. Sixth, the current provisions for recapture of depreciation deductions on the disposition of an asset ${ }^{47}$ are conceptually vulnerable, especially to the extent that straight line depreciation is recaptured. Finally, we have more reason to doubt the propriety of a bureaucratically defined Tax Expenditure Budget; if the Budget inhibits rational discussion in Congress of Code provisions' worth as matters of tax policy, it does far more harm than good.

\section{The Definition and Function of Depreciation - A PRIMER}

Before examining sinking fund depreciation and the question of the appropriateness of accelerated methods, a primer on depreciation may be helpful. Those readers well-versed in the traditional theory and methods of cost recovery through depreciation might like to skip to Section III.

\section{A. Cost Recovery}

Where a taxpayer incurs a current expense in connection with his trade or business, he usually will be allowed to deduct that expense during the tax year in which he pays or accrues it. ${ }^{48}$ So, for example, the cost a retail business incurs in advertising for the sale of its goods is a current deduction. However, the cost of purchasing an asset to be used for more than twelve months is usually not currently deductible. ${ }^{49}$ In theory, the taxpayer has not actually spent the dollars he paid for such an asset but rather has converted them into a different type of property. For example, if $T$ buys a typewriter at a cost of $\$ 800$ in Year One and if $T$ expects to use the typewriter in his business for five years, he cannot deduct the $\$ 800$ cost of the typewriter in Year One since he acquired an asset of like value.

But $T$ s typewriter will not last forever. Each year, a portion of the useful life of the typewriter will be exhausted until, after five years, the typewriter is no longer useful. In effect, each year that $T$ uses the typewriter, $T$ uses up a portion of the $\$ 800$ that he paid for it. An accurate measurement of $T$ 's net income for any one of those years will include a deduction of some amount to represent the portion of the $\$ 800$ cost that is properly allocable to that year. The allocation of the cost of a capital asset over the years in which the asset is

47. I.R.C. $\S \S 1245,1250$.

48. I.R.C. § 162. See also I.R.C. § 212.

49. I.R.C. § 263(a). 
employed is accomplished by a depreciation allowance. ${ }^{50}$ For tax purposes, depreciation is the amortization ${ }^{51}$ of the cost of an asset over the period that the owner employs it in a profit-seeking activity. ${ }^{52}$ During each year of the asset's useful life, the taxpayer deducts a portion of the asset's cost from his income, and reduces his basis accordingly. ${ }^{53}$

The present depreciation laws allow a cost recovery by allocating a deduction to each year of useful life, whether or not the amount so allocated exceeds the amount earned from the asset in that year. If a year's depreciation deduction exceeds that year's "income" from the property, the taxpayer may use the excess deduction against other income. Whether Congress should restrict depreciation deductions to an amount equal to the income from the depreciable property is a separate issue that I will not discuss in this Article.

The principal controversy over depreciation turns upon the methods employed to allocate the cost or basis of the asset over the life of the asset. If the taxpayer recovers part of the cost of the asset earlier than is proper (i.e., if too much depreciation is allowed in the early years of the asset's use), the taxpayer obtains a benefit to the extent of the tax reduction caused by the excessive deduction. The unwarranted depreciation deduction might never be recaptured; even if it is recaptured, the taxpayer receives the use of the extra tax reduction dollars until the excessive deduction is recaptured. The taxpayer gains the value of deferring the tax until a later date, and the dollar benefit of a tax deferral can be quite substantial. ${ }^{54}$ So, the

50. The tax laws have always provided for a depreciation deduction. See Act of Oct. 3, 1913, ch. 16, $\$$ II(B), II(6)(b), 38 Stat. 167, 172.

51. Depreciation is a type of amortization, and the terms are sometimes used interchangeably. Confusion may be caused because the tax law often employs these terms differently. For tax purposes, the term "depreciation" refers to an amortization deduction that is allowable under \$ 167. On the other hand, the phrase "amortization in lieu of depreciation" or some special form of amortization refers to an item of amortization that is deductible under a Code section other than § 167.

52. See M. Chirelstein, supra note 45, If 2.01 , at 24-32.

53. Not all assets have fixed useful lives, and therefore not all assets are depreciable. If a taxpayer purchases a nondepreciable capital asset (such as a share of corporate stock), he may recover his cost before he must recognize a gain on the sale of the asset; but with few exceptions, he may not recover the cost until he disposes of the asset. Thus, if a shareholder receives dividends on a share of stock, the entire amount received is treated as income from the shareholder's capital (i.e., not as a recovery of his cost). Since the share of stock has no ascertainable useful life, the shareholder's investment is treated as continuing in perpetuity, and the shareholder can recover his cost only by selling the share or by having it redeemed by the corporation. (In certain circumstances, where a distributing corporation has insufficient earnings and profits, a corporate distribution to a shareholder can constitute a return of his capital, but there are reasons for that treatment that do not contradict the principle described above. See D. Kahn, Basic Corporate TaXation 13-15, 20-25 (1973)).

54. See M. Chirelstein, supra note 45, \6.07, at 132-33. See also M. Alchian \& W. 
question of the proper allocation of cost (i.e., the depreciation method) is extremely important. Its importance is enhanced even further by its effect on the propriety of recapturing depreciation. ${ }^{55}$

\section{B. Elements of Depreciation}

Before considering the various methods of depreciation, we should first examine the three basic elements that affect the computation of depreciation: basis, useful life, and salvage value.

The "basis" of an asset is the cost of that asset for tax purposes. It therefore determines the total amount that a taxpayer may recover through depreciation. While basis often is the asset's actual cost to the taxpayer, it may also be acquired through other means. The basis of an asset acquired by gift is equal to the donor's basis plus part of the gift taxes paid. A taxpayer must adjust his basis in an asset at various times; for example, basis is reduced by no less than the amount of depreciation allowable, whether or not the taxpayer actually claimed a deduction and whether or not he obtained a tax benefit. The basis of an asset at a given point in time is usually referred to as the "adjusted basis" of the asset.

Under the Crane doctrine, ${ }^{56}$ a purchaser's basis in an asset he acquired subject to an encumbrance includes the amount of the encumbrance. Since each depreciation method is applied to the asset's basis, such a taxpayer may deduct costs that he has not yet paid leverage that is the keystone of many tax shelters. The various proposals to prevent the use of such leverage where the taxpayer is not personally liable to repay the debt secured by the encumbrance are worthy of much analysis, but this Article studies methods of depreciation; the question of how best to determine depreciable basis will have to be dealt with elsewhere.

The "useful life" of an asset is the amount of time that the taxpayer expects to use the asset in his business. The useful life may be shorter than the asset's physical life, since the taxpayer may expect to use the asset in his business for less than its physical life. For example, car rental businesses may use cars for less than two years because of their customers' demand to rent only new cars.

A depreciable asset is depreciated over its useful life. Of course, the taxpayer's estimate of useful life is merely a guess, and the im-

Allen, Exchange and Production: Competition, Coordination, ANd Control 144-49 (2d ed. 1977).

55. See Section V infra.

56. The Crane doctrine is named after the landmark case of Crane v. Commissioner, 331 U.S. 1 (1947). 
precision of such a guess has led to many disputes between the IRS and taxpayers. In 1971, Congress tried to minimize such disputes by allowing taxpayers to measure useful life under the asset depreciation range (ADR) system. One of the most important consequences of electing ADR is that if a taxpayer adopts a useful life for his assets in a range between $20 \%$ below and $20 \%$ above the life stated in a guideline promulgated by the IRS, 57 that life is conclusively deemed acceptable. As previously stated, the Treasury Department treats the ADR election as a tax expenditure. The ADR election is not available for buildings placed into service after the year 1973.58

The "salvage value" of an asset is the estimated amount for which the owner can sell the asset at the end of its useful life. The owner estimates salvage value when he first puts the asset into service. The salvage estimate is not revised periodically because of changes in market conditions. If the useful life of an asset is redetermined after it is placed into service, the salvage value must also be redetermined at that time. In determining the depreciation for certain personal properties, a taxpayer can elect to reduce salvage value by up to $10 \%$ of the asset's adjusted basis. ${ }^{59}$

Salvage value can affect depreciation in several ways. Under several methods of depreciation, the depreciation rate is applied to the difference between the basis of the asset and its salvage value. And under all methods, the taxpayer may never take so much depreciation that he would reduce his adjusted basis below the asset's salvage value. Salvage value also plays an important role in determining whether there is a single "proper" method of depreciation, and it is discussed in greater detail in Section IV of this Article.

\section{Methods of Depreciation}

A taxpayer may depreciate each asset separately (item depreciation) or in groups (multiple asset depreciation). Whether the taxpayer depreciates each item separately or whether he uses multiple asset groupings, he may choose among several permissible methods of depreciation to determine the appropriate rate. The three most commonly employed methods are "straight line," "declining balance," and "sum of the years-digits."

"Straight line" depreciation is determined by reducing the taxpayer's basis in the property by its salvage value and dividing the

57. I.R.C. $\$ 167(\mathrm{~m})$; Treas. Reg. § 1.167(a)-11(b)(4) (1971).

58. Rev. Proc. 77-3, 1977-1 C.B. 535.

59. I.R.C. $§ 167(f)$. 
difference by the useful life of the property. Under the straight line method, an equal amount of depreciation is allowable each full year. The percentage rate of depreciation under the straight line method is determined by dividing $100 \%$ by the useful life of the property. Thus, an asset with a five-year useful life will have a constant straight line rate of depreciation of $20 \%$.

Accelerated depreciation methods accelerate the recovery of cost above the straight line rate by granting larger depreciation deductions in the earlier years of an asset's use than are allowed in the later years. Unlike straight line depreciation, which is available for all depreciable properties, accelerated methods may be used only for certain types of tangible properties. ${ }^{60}$ Decelerated methods of depreciation provide less depreciation in the early years of an asset's use than in the later years.

"Declining balance" is an accelerated method of depreciation. Under the declining balance method, a multiple of the straight line percentage rate for the asset is multiplied times the adjusted basis of the asset, determined as of the beginning of the taxable year for which the depreciation deduction is allowable. The type of declining balance method is determined by the multiple of the straight line rate that is employed. Double declining balance (also referred to as $200 \%$ declining balance) uses a rate that is twice the straight line rate. ${ }^{61}$ Declining balance depreciation is computed without regard to salvage value, except that the aggregate amount of depreciation deductions that are allowable cannot exceed the difference between adjusted basis and salvage value. Taxpayers may use double declining balance only for certain types of properties, and to qualify, the taxpayer must be the first person to use the property. Another popular form is $150 \%$ declining balance, which uses a rate equal to 1.5 times the straight line rate. Taxpayers may use the $150 \%$ declining balance method for new buildings and for new or used tangible per-

60. A few types of properties, including some intangibles, may receive rapid amortization. See, e.g., I.R.C. $\$ 177$, allowing the amortization of the cost of acquiring a trademark or trade name over a 60 -month period.

61. The following example illustrates the operation of double declining balance depreciation. On January 1 of Year One, $R$ purchased a new machine to be used in his business. The machine cost $R \$ 5000$, had a useful life of 5 years and a salvage value of $\$ 800$. The straight line rate is $20 \%$, and so the double declining balance rate is $40 \%$. The first year's depreciation for the machine is $40 \% \times \$ 5000=\$ 2000$. The adjusted basis of the machine as of January 1 of Year Two is $\$ 3000$ ( $\$ 5000$ minus the $\$ 2000$ depreciation allowed for Year One). So the depreciation for Year Two is $40 \% \times \$ 3000=\$ 1200$. The depreciation for Year Three is $40 \% \times \$ 1800$ $=\$ 720$; and so on except that the aggregate amount of depreciation cannot exceed $\$ 4200$ (\$5000 minus the salvage value) assuming that the taxpayer did not elect to reduce salvage value to $\$ 300$ pursuant to I.R.C. $\$ 167(f)$. 
sonalty. ${ }^{62}$

The sum of the years-digits is an accelerated method that is available only for certain new personalty and for new residential rental realty. Under the sum of the years-digits method, a fraction is multiplied times the original basis of the asset (determined as of the date that the asset was put into service), reduced by salvage value. The numerator of the fraction is equal to the number of years of useful life remaining for the asset, and the denominator is equal to the sum of the digits from one through the asset's useful life (determined as of the date that the asset was first put into service). Thus, for an asset with a useful life of five years, the denominator is equal to $15(5+4$ $+3+2+1$ ); the fraction for the first year is $5 / 15$, the fraction for the second year is $4 / 15$, the fraction for the third year is $3 / 15$, and so on. At the end of the five-year useful life, $15 / 15$ or $100 \%$ of the depreciable amount (basis less salvage value) will have been allowed. In lieu of making the computation described above, the regulations provide a table for making the computation in a somewhat simpler manner.63

Other accelerated methods are available, ${ }^{64}$ but taxpayers most commonly use declining balance and sum of the years-digits. The Code imposes greater restrictions on the use of accelerated methods for realty than for personalty. ${ }^{65}$ Land is not a depreciable asset, but buildings are depreciable. The same accelerated methods are available for new residential rental realty (residential rental realty for which the taxpayer is the first user) as are available for tangible personalty. ${ }^{66}$ Other new depreciable realty, however, can be depreciated only on the straight line method, or on a $150 \%$ declining balance method, or on some method (other than the sum of the years-digits) that provides no greater amount of depreciation deductions than $150 \%$ declining balance during the first two-thirds of the

62. $125 \%$ declining balance is also used, principally for used residential rental realty.

63. Treas. Reg. $\$ 1.167($ b)-3(a)(2) (1956).

64. Two important ones are the units of production method and the income forecast method. Under the units of production method, the taxpayer estimates the number of units that will be produced by an asset, then allocates a proportionate amount of his cost less salvage to each unit. The income forecast method is used principally by persons owning and leasing TV or movie films. Rev. Rul. 64-273, 1964-2 C.B. 62. Such assets typically earn the bulk of their income in the first year or two of use, after which the amount of rental income drops dramatically. Under the income forecast method, a taxpayer is allowed a depreciation deduction equal to a fraction of the difference between his "cost" and salvage value. The numerator of the fraction is equal to the amount of income earned from the film that year and the denominator is equal to the total amount of income that the taxpayer estimates will be earned by the film over its useful life. Rev. Rul. 60-358, 1960-2 C.B. 68 .

65. I.R.C. § $167(\mathrm{j})$.

66. I.R.C. $\S 167(\mathrm{j})(2)(A)$. Residential rental property is defined in I.R.C. $\S 167(\mathrm{j})(2)(B)$. 
asset's useful life. ${ }^{67}$ No accelerated method at all may be applied to used realty unless it is used residential rental realty having a useful life of at least twenty years, in which case the taxpayer may use the $125 \%$ declining balance method (or some method that provides no greater amount of depreciation during the first two thirds of the asset's useful life). ${ }^{68}$

\section{COST RECOVERY FOR ANNUITIES AND FOR THE INSTALLMENT COLLECTIONS OF LOANS}

To analyze depreciation properly, it is usefül first to consider the cost recovery methods that best reflect the income earned from an annuity contract and from the collection of principal and interest on an outstanding loan. In Section IV of this Article, I will draw parallels between the cost recovery treatment of those items and the conceptual justification for accelerated depreciation.

\section{A. Annuities}

In the broadest sense, an annuity is a right to receive payments at periodic intervals. For income tax purposes, the regulations define the phrase "amounts received as an annuity" as "amounts which are payable at regular intervals over a period of more than one full year from the date on which they are deemed to begin, provided that the total of the amounts so payable or the period for which they are to be paid can be determined as of that date." 69 An annuity may either be "for life," of the annuitant or of anyone else, or it may be "for years": a fixed dollar amount payable periodically for a fixed number of years. In this discussion, I shall consider only the type of annuity that is purchased from an insurance company, and I shall concentrate on the annuity for years, payable annually. The cost of an annuity contract that provides for such annual payments is simpler to calculate than the cost of an annuity that is payable at more frequent intervals or the cost of an annuity for life, but the cost recovery principles applicable to all annuities are essentially the same. I will also assume that (as usually is the case) the annuitant cannot surrender the annuity contract to the company prior to maturity.

Suppose $D$ purchases an annuity contract to pay her $\$ 1,000$ per year for five years, and in exchange $D$ pays the insurance company a lump sum single payment. The insurance company will hold the

67. I.R.C. \& $167(\mathrm{j})(1)$.

68. I.R.C. \& 167(j)(4), (j)(5).

69. Treas. Reg. 1.72-1(b) (1956). 
premium and return it to $D$ in five annual installments. The unreturned balance will earn income for the company, and so it is willing to pay $D$ interest for the use of her funds. Thus, the aggregate amount paid to $D$ over the five-year annuity period will be greater than $D$ 's premium, and the difference constitutes the income that $D$ earns on her investment in the annuity. Since the company pays $D$ in fixed annual installments, it is necessary to determine the amount of each annuity payment to $D$ that is a recovery of her capital investment (i.e., a recovery of her cost) and the amount that is income to her.

We know the total amount the company will pay to $D$ and (since we know the amount of premium she paid) we know what part of the total is a recovery of cost and what part is income. But to tax $D$ 's income properly, we must determine the timing for the recovery of her cost and for the recognition of income. Should all of the payments be treated as a recovery of $D$ 's cost until she recovers her premium, and then all subsequent payments be treated as income? Should all payments be treated as income until $D$ receives the full amount of income to which she is entitled, and then all subsequent payments be treated as a recovery of her cost? Or should a portion of each annuity payment be treated as a recovery of $D$ 's cost and a portion treated as income, and if so, how should those portions be determined?

It is interesting to note how the tax law deals with these questions. Since 1954, the Code has treated a portion of each annuity payment as a recovery of cost and a portion as income. ${ }^{70}$ The Code allocates payments between cost recovery and income to exclude an equal percentage of each payment as a cost recovery and to treat a constant percentage of each payment as taxable income. ${ }^{71}$ The portion of each annuity payment that is excluded is computed by dividing the annuitant's investment in the annuity contract by the aggregate amount of annuity payments that the annuitant expects to

70. Prior to 1954, the tax treatment of annuities was quite different. Initially, the tax law treated all of the annuity payments as a retum of capital until the annuitant recovered the full cost and treated all additional payments as income. In 1934, Congress changed the tax law to provide that the annuitant treat $3 \%$ of each annuity payment as income and the balance as a recovery of cost until he fully recovers his costs, after which he must treat all of the payments as income. M. Chirelstein, supra note 45 , If 2.02 , at 33.

71. A different method of allocation is applied in the case of an annuity provided by an employer where the employee's own investment in the annuity is so small that the aggregate amount payable under the annuity within three years after payment commences is equal to or exceeds the employee's investment. In such cases, the employee excludes the annuity payments from income until he recovers his cost and thereafter treats the payments as income. I.R.C. $\$ 72$ (d). This is a de minimis rule to avoid the administrative nuisance of allocating cost among a number of annuity payments where the amount of cost recovery is relatively small. 
receive (the "expected return"). ${ }^{72}$ In the case of an annuity for years where the payments are of equal amounts, the expected return is equal to the amount of the annual annuity payment times the number of payments the company will make. ${ }^{73}$ Thus, if $D$ buys a five-year annual annuity, she will exclude $1 / 5$ of the premium cost from her gross income each year. $D$ recovers her cost ratably over the five annual payments and also allocates her interest ratably over the five-year period.

In his excellent primer on federal income taxation, Professor Chirelstein questions whether the current tax treatment of annuity payments is sensible. ${ }^{74}$ Professor Chirelstein reasons that the current system permits a deferral of income (and in the case of an annuity for life, there may be a forgiveness of income) in that it allows the annuitant to recover a larger portion of his cost in the early years of the annuity than Chirelstein believes appropriate. He points out that an annuitant is in the same position as a lender who has loaned money to be repaid in installments with interest. He states, "As anyone knows who has ever paid off a home mortgage, interest always bulks very large in the early years (with repayment of principal correspondingly small), while the reverse relationship holds true of payments towards the end." $75 \mathrm{He}$ concludes that the purpose of permitting an even distribution of the recovery of cost is to provide roughly constant after-tax income for the annuitant and to prevent annuitants for life from incurring larger tax bills when they are older and would find it difficult to adjust their standard of living to a decreasing amount of net income. Thus, "[i]n this latter respect, $\S 72$ is simply one of a jumble of tax relief measures whose purpose is to give assistance to the aged . . . ."76

Although that view has merit insofar as it relates to the treatment of annuity payments made under an annuity for life contract to an annuitant who has outlived his life expectancy, ${ }^{77}$ Professor Chirelstein errs, although admittedly quite lucidly, when he asserts that an annuitant actually receives more interest income in the early years of payment than in the later years. Professor Chirelstein points to the treatment of mortgage installment payments as evidence in support of his conclusion, but his argument rests on two unsupported as-

72. I.R.C. $\$ 72(b)$.

73. Treas. Reg. $\S 1.72-5$ (c) (1956).

74. M. Chirelstein, supra note $45, \mathbb{1} 2.02$, at 34-35.

75. Id. at 34 .

76. Id. at 35 .

77. See text at notes 86-88 infra. 
sumptions: first, that the practice of allocating larger amounts of interest to the earlier mortgage payments is an accurate method of reflecting interest income, and second, that it is the only accurate method of reporting such interest income. We will examine the proper treatment of installment repayments of loans later, but first let us examine directly the proper treatment of annuity payments. To do so, we must understand how the cost (or premium) for an annuity contract is determined. Consider the following example:

On March 1 of Year Zero, $X$ (who reports her income on the cash method) determines that she would like to have $\$ 1$ paid to her one year later (on March 1 of Year One). $X$ asks the Friendly Insurance Company what amount they would charge her now, on March 1 of Year Zero, to provide her with a contractual right to receive $\$ 1$ on March 1 of Year One. The company first determines what rate of interest it will pay for the use of $X$ 's money. Let us assume that the company will pay interest at a $6 \%$ rate compounded annually. The company then calculates the amount which invested at a $6 \%$ rate for one year will yield $\$ 1$ at the end of the year - that is, the original investment plus the $6 \%$ interest will total $\$ 1$. In effect, the company discounts $\$ 1$ at a $6 \%$ rate to determine the present value of the right to receive $\$ 1$ one year hence. This amount (the present value of $\$ 1$ ) can either be computed algebraically ${ }^{78}$ or the amount can be determined under tables provided for convenience of computation. ${ }^{79}$ The present value of $\$ 1$ discounted for one year at a $6 \%$ rate is $94.3 \$$; if $94.3 \$$ is invested at $6 \%$, it will yield $5.7 \$$ at the end of the year, which will provide an aggregate of $\$ 1$ in principal plus interest. When $X$ receives $\$ 1$ on March 1 of Year One, she will have income of 64 , and $94 \$$ will be a return of her capital. So, rounding off the $94.3 \$$ figure, the company will charge $X$ a premium of $94 \$$ for the right to receive $\$ 1$ one year later.

After thinking over the company's proposal, $X$ decides that she does not really need $\$ 1$ one year from now, but instead wishes to receive $\$ 1$ two years later, on March 1 of Year Two. $X$ asks the company how much she must pay now to acquire the right to $\$ 1$ in two years. To compute that amount, the company discounts $\$ 1$ at a $6 \%$ compounded rate for two years. The resulting figure, $89 \phi$, is the present value at a $6 \%$ compounded rate of $\$ 1$ payable two years later.

78. The present value $(P)$ of a stated amount $(A)$ one year hence is equal to the result of dividing the stated amount $(A)$ by an amount equal to 1 plus the rate of discount (r). So our formula is $\mathrm{P}=\frac{\mathrm{A}}{1+\mathrm{r}}$. In the example in the text $\mathrm{A}=\$ 1$ and $\mathrm{r}=6 \%$. So, $\mathrm{P}=\frac{\$ 1}{1.06}=$ 94.36.

79. See, e.g., M. Alchian \& W. Allen, supra note 54, at 148, Table 7-1. 
Again, the present value can be determined either algebraically ${ }^{80}$ or by resorting to tables which have already made those calculations. ${ }^{81}$ So $X$ must pay the company $89 \$$; and when she receives a $\$ 1$ payment two years later, she will receive $11 \$$ of income and 894 as a return of her capital. ${ }^{82}$

After further reflection, $X$ decides that she would prefer to purchase the right to receive $\$ 1$ three years later, on March 1 of Year Three. The company informs $X$ that the cost of a right to $\$ 1$ in three years is $84 \$$. If $X$ purchases the right to that dollar, she will receive 164 of income in Year Three, and the remaining $84 \$$ of the dollar she receives will be a return of her capital.

$X$ finally decides that what she really wants is to have $\$ 1$ paid to her one year later (on March 1 of Year One), an additional $\$ 1$ paid to her two years later (on March 1 of Year Two) and a final dollar paid to her three years later (on March 1 of Year Three). She wants an annuity of $\$ 1$ per year for three years. The cost of that annuity is easily computed. The company merely adds together the costs (which were computed above) for the right to $\$ 1$ in one year (94\$), in two years $(89 \$)$, and in three years $(84 \$) .83$ The total of those three present values is $\$ 2.67$, which is the cost to $X$ of an annuity of $\$ 1$ per year for three years. ${ }^{84}$ It may be helpful to set forth the foregoing information in tabular form.

(March 1, Year Two)

(March 1, Year Three)

\begin{tabular}{|c|c|c|c|c|}
\hline Years & Cost & $\begin{array}{l}\text { Amount } \\
\text { Received }\end{array}$ & $\begin{array}{c}\text { Interest } \\
\text { Received }\end{array}$ & $\begin{array}{c}\text { Return of } \\
\text { Capital }\end{array}$ \\
\hline 1st & $94 \uparrow$ & $\$ 1$ & 64 & $94 €$ \\
\hline 2nd & $89 c$ & $\$ 1$ & 114 & 894 \\
\hline $3 \mathrm{rd}$ & $84 c$ & $\$ 1$ & 164 & $84 屯$ \\
\hline
\end{tabular}

A cursory glance at the above table is sufficient to see that the

80. The formula for computing the present value, $(\mathrm{P})$ at a compounded rate (I) 'of a stated amount $(A)$ payable at a future date is $P=\frac{A}{(1+r)^{i}}$ where $t=$ the number of years in the future in which the payment is to be made. In the example above, where $\$ 1$ is to be paid two years later, the formula is: $P=\frac{\$ 1}{(1.06)^{2}}=\frac{\$ 1}{1.12}=894$.

81. See note 79 supra.

82. Since $X$ has an unrestricted right to the $5 \notin$ of interest income that was earned at the end of Year One (6\% of $89 \leftarrow$ is about 54 ), $5 \uparrow$ of the 114 interest received in Year Two may well have accrued in Year One under accrual basis reporting. But, $X$ reports her income on the cash method, and so none of the interest is reported by her until she receives it in Year Two. Moreover, since $X$ has no right to surrender the annuity contract to the insurance company in Year One and thereby obtain possession of the $5 \mathbb{t}$ of interest earned in that year, there is no possibility of $X$ 's having constructively received the interest in Year One. As noted in Section I supra, the cash method of reporting income is an integral part of our tax system. The exclusion from $X$ 's Year One income of the 54 of accrued but unpaid interest is not a tax subsidy or preference; it is merely normal income measurement under the cash method.

83. See M. Alchian \& W. Allen, supra note 54, at 149.

84. See id. at 149, 151, \& 152, Tạble 7-3. 
portion of the annuity payments that constitutes interest income to $X$ is less in the early years of payout than in the later years, and conversely a greater portion of the early annuity payments constitutes a recovery of $X$ 's cost. But is it appropriate to compartmentalize the annual annuity payments so that the cost of each year's payment is separately computed and deemed to be recovered in the year of payment? For example, after the expiration of one year, the interest, at a $6 \%$ rate, on the entire $\$ 2.67$ paid by $X$ is 164 . Should, as Professor Chirelstein asserts is conceptually correct, the entire 164 of accrued interest be treated as having been paid to $X$ on March 1 of Year One so that only 844 of the $\$ 1$ she received on that date is to be treated as a recovery of her cost? In my view, it should not. There is no compelling reason to allocate to $X$ 's payment in Year One the income earned on money paid for the right to receive annuity payments in Years Two and Three.

Stating it slightly differently, of the $\$ 1$ payment that $X$ received in Year One, 944 is a return of her capital and 64 is interest. Of the 164 interest earned on $X$ 's $\$ 2.67$ premium, $10 \$$ of that amount represents accrued but unpaid interest. But since $X$ reports on the cash method of accounting, the $10 \$$ of accrued but unpaid interest should not be taxable to her.

Consider the following alternative for $X$. Instead of purchasing a three-year annuity contract from the Friendly Insurance Company, suppose she pays them $94 \$$ for the right to receive $\$ 1$ one year later. $X$ then travels across town to the rival Cheerful Insurance Company, and she pays them $89 \$$ for the right to receive $\$ 1$ two years later. $X$ then visits a third company, the Neighborly Insurance Company, and she pays them $84 \notin$ for the right to receive $\$ 1$ three years later. In that circumstance, there is no doubt that $X$ will recognize 64 of income in Year One, 114 of income in Year Two, and 164 of income in Year Three. Surely the economics of the transaction are not altered if $X$ purchases the right to the three years of annual payments from a single insurance company. The tax consequences ought to be the same whether $X$ uses one insurance company or three companies.

It is likely true that Congress provided in the tax law for an equal allocation of the return of an annuitant's capital over the annuity payments for nonrevenue policy reasons. The apparent purpose, as noted above, is to maintain an approximately equal amount of aftertax dollars for the annuitant so that no radical adjustments need be made in the annuitant's life style as would occur if the rate of recovery were to change every year. However, contrary to Professor 
Chirelstein's assertion that the current tax law grants a deferral to the annuitant, we have seen a strong case for the proposition that the tax law requires the annuitant to report more income in the early years of payment than is actually attributable to those payments.

Nevertheless, there is a colorable claim that the interest income to an annuitant should be allocated so as to decrease with each payment. Arguably, the purchase of an annuity from one insurance company can be treated as a single investment and need not be divided into multiple purchases for successive annuity payments merely because the annuitant could have purchased the right to each annual payment separately. ${ }^{85}$ The arguable justifiability, however, of allocating all accrued interest to each annuity payment is a far cry from proof that such an allocation is the only permissible method of reporting income. At the very least, the case for treating a cash method annuitant's taxable income as increasing each year is as strong as the case for treating it as decreasing each year. The scheme that Congress adopted in section 72 can be regarded as a justifiable compromise between those two polar positions. Obviously, Congress had no such compromise in mind when it adopted section 72 , but the Code's position midway between two acceptable theses suggests that it adequately comports with economic reality. In any event, as indicated above, I find the case for an increasing rate of taxable income to a cash method annuitant to be overwhelming, and so if there is any "subsidy" in that aspect of section 72 , it is from the annuitant to the government.

Before departing from the subject of annuities, a brief consideration of the tax treatment of an annuity for life is in order. Under section 72, the portion of a payment under an annuity for life contract that is to be excluded as a recovery of capital is computed in the same manner as is done for an annuity for years. One difference is that the expected return from an annuity for life contract must be estimated, whereas the amount of return from an annuity for years contract usually is certain. 86 The expected return from an annuity for life contract is determined by using the life expectancy of the annuitant, as provided in tables set forth in the regulations. ${ }^{87}$

If an annuitant dies precisely at the expiration of his life expec-

85. Cf. Meyer v. United States, 364 U.S. 410 (1960) (6-3 decision) (annuity for years and contingent life annuity, payable as settlement of a single life insurance "policy," are treated as single "property" for purposes of marital deduction).

86. Under certain circumstances, however, a contract may provide for an increase in the interest rate.

87. Treas. Reg. $§ 1.72-5(a)$ (1956). The tables are set forth at Treas. Reg. $\$ 1.72-9$ (1954). 
tancy, during his life he will have recovered the exact amount of his cost and will have reported the balance of the payments made to him as income. If an annuitant dies prior to attaining his life expectancy, he will not recover his cost, but nevertheless the Code permits no loss deduction. If an annuitant outlives his life expectancy, he may continue to exclude from income the same portion of each payment made after the expiration of his life expectancy as he would have excluded if the payment had been made prior to that date. ${ }^{88}$ This current position of continuing the exclusion ratio after the annuitant has recovered all of his cost constitutes a change from the pre-1954 Code, under which all payments in excess of the annuitant's cost were treated as income. The likely reason for continuing the exclusion ratio is the previously stated policy of maintaining a roughly constant amount of after-tax dollars for elderly, retired persons. It would be especially harsh to impose an increased tax burden on annuity payments at a time when the annuitant is of advanced age and likely has increased medical and related costs and burdens. This aspect of section 72 is designed as a benefit to the elderly, but it is an especially rational one, and as we have seen, that benefit is not increased by the asserted failure of the government to tax the annuitant on larger amounts of income in the earlier years of the annuity payments.

\section{B. Collection of Loans}

Professor Chirelstein pointed to the treatment of mortgage installment payments to support his contention that all accrued interest should be allocated to an annuity payment. ${ }^{89}$ Various commentators have used the same analogy to loan repayments to support the thesis that from an economic view a decelerated method of depreciation is the only proper method. ${ }^{90}$ The question of the proper allocation of interest and principal to installment loan repayments is therefore relevant to the examination of depreciation. Before discussing that question, let us consider the tax law's provision for the allocation of interest to loan repayments.

Under the tax law, an arm's length agreement between a debtor and a creditor about how to allocate principal and income to installment payments on an outstanding loan is determinative for tax purposes. ${ }^{91}$ Thus, if a creditor and a debtor who report their income on

88. I.R.C. \& 72(b); Treas. Reg. 1.72-4(a)(4) (1956).

89. M. Chirelstein, supra note 45.

90. Id. \ 6.07, at 135. See also S. SURREY, supra note 2, at 389 n.138.

91. See Bayou Verret Land Co., 52 T.C. $971,985-86$ (1969), revd. on other grounds, 450 
the cash method agree that all installment payments on a loan are to be treated as repayments of principal until the debtor repays the entire principal, the creditor does not recognize any income until the payments to him exceed the amount of the loan. ${ }^{22}$ In such a case, the creditor recovers all of his cost before payments to him constitute income. If the parties do not expressly agree to an allocation of principal and interest, all interest accrued at the date of an installment payment is allocated to that payment. ${ }^{93}$

A creditor and debtor typically allocate all accrued interest to each installment loan repayment and treat the balance of the payment as principal. As indicated by the rulings and cases cited above, that is not the exclusive method of allocation for cash method taxpayers, but it is the one that is most commonly employed for home mortgages. Yet the popularity of such an allocation does not make it the best or the only proper method for accurately reporting the interest income.

The great similarity between a loan repayable in fixed installments and an annuity contract suggests that an accurate method of reporting income from one should also be accurate for reporting income from the other. As demonstrated above, the most accurate method of reporting annuity income is one where the annuitant recovers a greater amount of the cost (i.e., principal) in the early years of the contract payments than in the later years, but other methods may well be acceptable alternatives. In any event, allocating less to interest in the early years provides a measure of net income that is at least as accurate as any other. Accordingly, for persons on the cash method, an acceptable method of allocating interest to an installment payment on a debt is to allocate less interest in the early years and more in the later years. If that is an acceptable method, and the current tax law clearly permits it if the parties agree, why do the

F.2d 850 (5th Cir. 1971); Huntington-Redondo Co., 36 B.T.A. 116 (1937), acq. in result 1937-2 C.B. 14; Rev. Rul. 72-2, 1972-1 C.B. 19, 20; Rev. Rul. 63-57, 1963-1 C.B. 103. A possible exception to the general rule that the parties can allocate principal and interest as they see fit is that the allocation of interest will not permit the debtor a deduction if (under I.R.C. § 446(b)) a deduction would not clearly reflect income. See Mason v. United States, 453 F. Supp. 845, 848 (N.D. Cal. 1978) (dictum). It is unlikely that any allocation of accrued interest or of principal would violate the clear reflection of income requirement unless there was a pre-payment of interest which had not yet accrued. See, e.g., Burck v. Commissioner, 63 T.C. 556 (1975), affd., 533 F.2d 768 (2d Cir. 1976).

92. See Huntington-Redondo Co., 36 B.T.A. 116 (1937), acq. in result 1937-2 C.B. 14; Rev. Rul. 72-2, 1972-1 C.B. 19, 20, Rev. Rul. 63-57, 1963-1 C.B. 103. In Huntington-Redondo, the agreement was made after the installment payment was received, but the court treated the agreement as binding for tax purposes because the agreement was made prior to the end of the taxable year in which the installment payment was received.

93. See Mason v. United States, 453 F. Supp. 845, 848 (N.D. Cal. 1978); Motel Corp. v. Commissioner, 54 T.C. 1433,1440 (1970). 
parties to a home mortgage loan choose to allocate interest by such a different method? I can offer only a few speculations on why the allocation of interest first is so popular.

The majority of the large lenders are corporations who report their income on the accrual method. Such lenders have to recognize interest in the year of accrual, regardless of how the parties formally allocated it. Such lenders would naturally tend to allocate payments in an interest-first fashion, to give the borrower a tax benefit at no tax detriment to themselves. Moreover, the commercial benefits to a corporate lender of increasing its earnings per share could outweigh the tax detriment of receiving interest payments first, even if such a detriment existed. Many commercial loans are not repayable in fixed installments of even amounts. Some debts are payable in one lump sum, principal and interest, at maturity. Some debts require that only interest be paid at fixed intervals until maturity, when the debtor must repay the loan in full. In that situation, the creditor is more like a shareholder of corporate stock than like an annuitant. The creditor's investment remains intact while he collects income on it until maturity; in essence he has income on a perpetual investment. At maturity, the creditor can either prolong the loan or demand payment. Most corporate and government bonds are examples of such "interest only" loans. In Section IV, I discuss whether a portion of the current payments on such a nonwasting asset should be treated as a return of capital, as a matter of tax policy. ${ }^{94}$ In that Section, I also offer some ideas about why the present tax laws choose not to characterize current payments in that manner and instead treat all current payments on a nonwasting asset as interest. For present purposes, it is enough to note that the Code taxes commercial loans in that manner.

A similar commercial loan arrangement provides for the periodic payment of interest plus an amount of principal substantially less than the amount necessary to amortize the loan fully by the time of maturity, when the debtor must make a large payment of principal (sometimes referred to as a "balloon payment"). Again, for such loans the accrued interest has been allocated first to periodic payments. In light of their familiarity with interest-only loans, commercial lenders may well have identified an installment repayment loan (such as a home mortgage) with them rather than with the more closely analogous annuity contract; and so they allocate interest first to each installment payment just as they do for an interest-only loan.

94. See text at note 119 infra. 
Another consideration is that the tax deductibility of interest payments makes the early allocation of larger amounts of interest highly attractive to the debtor. Just as a lender adjusts interest rates according to the going market, so might competition encourage him to allocate interest first. Even if the lender is a cash method taxpayer so that such an allocation disadvantages him, he may be forced by accrual method competitors to offer the debtor favorable tax terms.

A third possible explanation is that a lender prefers to receive interest first so that the principal of the debt is reduced as slowly as possible. If the debtor defaults, the lender will have a more advantageous position as a creditor of unpaid principal than he would as the creditor of defaulted interest. One reason for this advantage is that home mortgage loans bear simple interest, and.typically no interest is payable on defaulted interest. By attributing an installment payment to earned interest, the lender maximizes the amount of interest he will earn of the unpaid debt in the event of a subsequent default. Indeed, because only simple interest is computed on the unpaid balance of the principal, the total amount of interest will be greater (even without a default) if the principal balance is reduced at a slower rate.

Finally, the practice of allocating interest income first is the simplest method to apply and to explain to the borrower. A loan repayment schedule where interest is allocated by discounting the payment for its present value at the time that the loan was made would boggle the mind of the average home owner.

Regardless of the reason for the common practice of allocating all accrued interest to periodic installment payments on a home mortgage loan, its generality does not prove that the allocation provides an accurate measure of net income, much less that it is the only accurate measure. There are a variety of methods of allocation that provide an acceptable measure of net income. The tax law impliedly recognizes that no one method is exclusively correct by permitting the parties to make whatever allocation they agree upon. ${ }^{95}$ Since the parties are at arm's length, and since the debtor and the creditor sometimes have conflicting tax interests in the method of allocation employed, there is some reason for the government to leave to the parties how to allocate interest. ${ }^{96}$ In contrast, the government does

95. See note 91 supra and accompanying text.

96. The freedom granted to choose whatever cost recovery method the parties wish may be too liberal in that it permits manipulation. The tax law perhaps should be amended to permit only a single method of cost recovery allocation or at least to limit the number and extent of elections available to the parties. 
not permit the parties to select the allocation method for annuities, because there the government wants an annuitant's after-tax income to remain roughly constant so that his standard of living does not fluctuate dramatically.

\section{The “Correct” Method of Depreciation to Measure NET INCOME}

Until 1954, taxpayers seldom used accelerated depreciation even though the tax laws permitted some types of accelerated depreciation. The principal accelerated method used before the adoption of the 1954 Code was the $150 \%$ declining balance method. ${ }^{97}$ Double declining balance and the sum of the years-digits methods are creatures of the 1954 Code, which multiplied the permissible types of accelerated depreciation. The avowed purposes of the liberalization were to stimulate capital investment and to encourage risk-taking expansion. ${ }^{98}$ But while Congress was not seeking to improve measurement of income, its allowance of accelerated depreciation should be called a "tax expenditure" only if and to the extent that the deduction distorts the measurement of the taxpayer's net income. It has been widely asserted and assumed that accelerated depreciation causes such a distortion, ${ }^{99}$ especially when applied to buildings; in this Section, I challenge that assumption.

The commentators who treat accelerated depreciation as a tax preference urge that the proper measure of a year's depreciation allowance is the decline in the property's value during that year. ${ }^{100}$ The commentators do not suggest that a depreciable item should actually be valued at the end of each year; such a system would not be practical to administer. Rather, they urge that the depreciation schedule should generally reflect the manner in which properties de-

97. Cf. H.R. REP. No. 1337, 83d Cong., 2d Sess., 22 A48, reprinted in [1954] 3 U.S. CoDE CoNG. \& AD. NEws 4017, 4047, 4184-85 (although $150 \%$ declining balance is available, most taxpayers use straight-line depreciation). In appropriate circumstances, other accelerated methods were permitted, however, even prior to 1954. For example, in Concord Cab Corp., 18 T.C. 1009 (1952), the court noted with approval that the Commissioner had allowed the taxpayer corporation to depreciate the cost of taxicabs that it acquired, and which had a four-year life, at an accelerated rate so that $45 \%$ of the cost was deductible in the first year, $25 \%$ the second year, $20 \%$ the third year and $10 \%$ the fourth year. 18 T.C. at 1012 .

98. S. REP. No. 1622, 83d Cong., 2d Sess. 25-26 (1954).

99. See M. Chirelstein, supra note 45.

100. See, e.g., Eisner, Effects of Depreciation Allowances for Tax Purposes, in 2 TAX RevISION COMPENDIUM 793, 797 (House Comm. on Ways and Means 1959), reprinted in READINGS IN FEDERAL TAXATION 318, 322 (1970); Taubman \& Rasche, Economic and Tax Depreciation of Office Buildings, 22 NATL. TAX J. 334 (1969); M. ChirelsteIN, supra note 45, \ 6.07, at 133; S. SURREY, supra note 2, at 237; W. ANDREWs, BASIC FEDERAL INCOME TAXATION 452 (2d ed. 1979). 
cline in value over time. They point out that the actual decline in value of many properties, especially of buildings, is far less than the amount of depreciation allowable under the straight line method and assert that accelerated methods aggravate the distortion that already exists under the straight line method. One study concluded that the "true depreciation" of office buildings in the first year of use is only $1 / 10$ of the amount of depreciation allowable under the straight line method and the "true depreciation" of apartment houses is $1 / 4$ of the straight line depreciation. ${ }^{101}$ To understand why property values decline less in the first year than even the amount allowed under straight line depreciation, and to understand why such a decline in value is not representative of "true depreciation," a careful consideration of so-called sinking fund depreciation will be helpful. Before examining sinking-fund depreciation, however, let me summarize the reasons that fluctuations in market prices do not, and should not, affect the proper amount of depreciation that is allowable for tax purposes.

Depreciation is an allocation of the cost an owner incurs in acquiring an exhaustible asset. The amount of cost that is allocable to the exhaustion of a portion of an asset's life should not be reduced or increased merely because external market conditions have changed the value of the remaining years of useful life: such unrealized appreciation or depreciation is not taken into account for tax purposes until realized. A brief example with simplified facts should be sufficient to illustrate the irrelevance of changes in market prices.

Suppose in Year One, $E$ wishes to acquire fire insurance for her business property. The annual premium for fire insurance at that time is $\$ 1000$. $E$ decides to purchase fire insurance for a five-year period at a cost of $\$ 1000$ per year, payable in one lump sum of $\$ 5000$ in Year One. Of course, the portion of the premium payment required for Years Two to Five would be discounted to present value; but in the interest of simplicity, we will ignore that detail and have $E$ pay the full amount of $\$ 5000 .{ }^{102}$ After one year, $1 / 5$ of the fire insurance contract has been exhausted and $E$ paid $\$ 1000$ for that year's protection (1/5 of the $\$ 5000$ premium). $E$ now has a fire insurance contract for four remaining years. Ignoring discounts for present value, the contract for the four remaining years is worth $\$ 4000$ if market conditions have not altered. But what if by the end of the

101. Taubman \& Rasche, Subsidies, Tax Law, and Real Estate Investment, Economics of Federal Subsidy Programs Part 3 - TaX Subsidies, Joint Economic Committee, 92d Cong., 2d Sess. 343-44 (1972), quoted in S. SURREY, supra note 2, at 237 n.113, 238 n.118.

102. The example is worked through using discounting in text following note 113 infra. 
year the annual premium charged for fire insurance has increased to $\$ 1200$ because of rising costs? $E$ 's fire insurance for the remaining four-year period would then be worth $\$ 4800$. The increase in market value of the remaining $4 / 5$ of the useful life of the insurance contract does not alter the exhaustion of $1 / 5$ of the insurance contract in the prior year, insurance that cost $E \$ 1000$. The cost should be allocated according to the value that existed at the time that $E$ purchased the policy. If $E$ had purchased five separate fire insurance contracts, one for each successive year, she clearly would deduct $\$ 1000$ for the exhaustion of the first contract, regardless of the increase in value of the four remaining contracts at the end of that year. Similarly, a decline in the cost of fire insurance, resulting in a loss in value of the remaining $4 / 5$ of the useful life of the five-year contract that $E$ purchased, should not increase the amount of depreciation allowable to $E$ for that first year.

The Supreme Court expressly noted the irrelevance of market price fluctuations to depreciation allowance in Fribourg Navigation Co. v. Commissioner. ${ }^{103}$ Midway in the taxable year in question, the taxpayer had sold a ship for more than the ship's adjusted basis at the beginning of the year. The ship's value had risen dramatically because of the 1956 Suez crisis. The taxpayer claimed a depreciation deduction for the portion of the year prior to the sale. The Supreme Court allowed the deduction, holding (in effect) that the increase in market value of the ship did not affect the allocation of cost to the exhaustion of a portion of the useful life of that asset.

Yet the observation that the actual decline in property values during the first year of use is less than the straight line depreciation allowance does not depend upon changes in market conditions. The "sinking-fund depreciation" concept is a sophisticated analysis that demonstrates that even though market conditions remain constant, an asset that produces constant annual income will decline less in value in the early years of its use than in the later years. Tax specialists have widely accepted sinking-fund depreciation as providing the most accurate, or perhaps the only correct, measurement of true depreciation. Professor Chirelstein provides one of the clearest explanations of sinking-fund depreciation in his excellent book on income taxation, ${ }^{104}$ and I borrow the following example from that book to illustrate the concept.

The analysis begins with an assumption that the market value of

103. 383 U.S. 272, 276 (1966).

104. M. Chirelstein, supra note $45, \prod 6.07$, at 133-35. 
an asset is the present value of the income stream that the asset will produce. In effect, the estimated income from each year of the asset's useful life is discounted to present value, and the sum of those present values equals the market value of the asset. Now suppose that on January 1 of Year One, $K$ purchases a machine for $\$ 4000$. $K$ plans to use the machine in his business, and he estimates that the machine will produce $\$ 1200$ of revenue each year for five years, the useful life of the machine. To simplify the problem, let us assume that $K$ anticipates no repairs or maintenance expenses and that $K$ acquires the $\$ 1200$ of annual revenue in one lump sum at the end of each year. Then the expected rate of return from the machine is slightly more than $15 \%$. This is computed by determining the discount rate that will produce a $\$ 4000$ present value for an income stream of $\$ 1200$ per year for five years. If the $\$ 1200$ revenue for each year is discounted at a little more than a $15 \%$ compounded rate, the present value is the $\$ 4000$ that $K$ paid for the machine. We will assume that others also could earn $\$ 1200$ annually from the use of the machine, and so $15 \%$ is the market discount rate for the machine.

The theory of sinking-fund depreciation is that the true depreciation of the machine for a given year is the difference between the present value of the remaining income stream, determined at the beginning of the year, and the present value of the remaining income stream, determined at the end of that year. The following schedule, taken from Professor Chirelstein's book, illustrates how that computation is made.

\begin{tabular}{|c|c|c|c|c|c|c|c|}
\hline & \multirow[t]{2}{*}{$\begin{array}{l}\text { Present Value } \\
\text { of Investment }\end{array}$} & \multicolumn{4}{|c|}{$\begin{array}{c}\text { Present Value } \\
\text { of Remaining Payments }\end{array}$} & \multirow[b]{2}{*}{5} & \multirow[t]{2}{*}{$\begin{array}{l}\text { Annual } \\
\text { Loss in } \\
\text { Present } \\
\text { Value }\end{array}$} \\
\hline & & 1 & 2 & 3 & 4 & & \\
\hline \multirow[t]{2}{*}{$\begin{array}{l}\text { Start of Year } 1 \\
\text { End of Year } 1 \\
\text { End of Year } 2 \\
\text { End of Year } 3 \\
\text { End of Year } 4 \\
\text { End of Year } 5\end{array}$} & $\begin{array}{r}\$ 4,000 \\
3,427 \\
2,427 \\
1,950 \\
1,045 \\
-0-\end{array}$ & $\$ 1,045$ & $\begin{array}{r}905 \\
1,045\end{array}$ & $\begin{array}{r}790 \\
905 \\
1,045\end{array}$ & $\begin{array}{r}687 \\
790 \\
905 \\
1,045\end{array}$ & $\begin{array}{r}573 \\
687 \\
790 \\
905 \\
1,045\end{array}$ & $\begin{array}{r}\$ 573 \\
687 \\
790 \\
905 \\
1,045 \\
\end{array}$ \\
\hline & & & & & & Total: & $\$ 4,000$ \\
\hline
\end{tabular}

In connection with the above schedule, Professor Chirelstein states:

The last column shows the true measure of economic cost from year to year and indicates that the correct apportionment method is one which starts low and rises: $\$ 573$ in Year 1 , then $\$ 687, \$ 790, \$ 905$, and finally $\$ 1,045$ in Year 5. The resulting schedule of taxable income, of course is the inverse: $\$ 627$ of taxable income in Year $1, \$ 513$ in Year 2, \$410 in Year 3, $\$ 295$ in Year 4 and finally $\$ 155$ in year 5. Income is thus 
higher in the earlier years than in the later. ${ }^{105}$

The conclusion that Professor Chirelstein derives from this analysis is that a decelerated method of depreciation is the only accurate measurement of net income. The market value of an item of property declines less in its early years of use, and so a smaller amount of cost recovery (i.e., depreciation) should be allocated to those early years. The correct amount of depreciation for any given year is said to be equal to the value at the beginning of that year of the revenue the owner will receive in the last year for which he expects to use the asset.

The advocates of decelerated depreciation, including Professor Chirelstein, typically do not urge the abolition of straight line depreciation as a permissible method. They recognize that the anticipated income stream of an asset is more difficult to determine than that of an annuity or a self-liquidating loan; an asset used in a business often does not produce a level amount of revenue each year. But, Professor Chirelstein concludes, "In principle, nevertheless, sinkingfund is the only proper method of apportioning the taxpayer's capital investment in accordance with the economic cost of use." 106

Most surprisingly, public response to the sinking-fund concept was uncritically accepting. The "model" depreciation schedule is counter-intuitive and should have inspired some skeptical examination of the sinking-fund premises. Referring back to the example above, if one were to ask $K$ for which year's income he paid the most, the answer would be the income from Year 1 . In valuing the machine at $\$ 4000, K$ valued the first year's income at $\$ 1045$ (as shown on the schedule) and he valued the fifth year's income at only $\$ 573$. Yet, under the sinking-fund concept, $K$ finds that, almost magically, his true "cost" of receiving the income for Year 1 was the $\$ 573$ he paid for the fifth year's income, and his true cost of receiving the income earned in Year 5 was the $\$ 1045$ he paid for the first year's income.

The fallacy in the sinking-fund concept is that it is premised on an assumption that the exhaustion of one year's useful life of an asset should be offset by the unrealized appreciation in the remaining years of life that arises by virtue of the passage of time. Referring back to the example above, the last four years of the life of the machine had a greater value after the expiration of one year's time because the revenue for those years was discounted one fewer year.

105. Id. at 134-35 (emphasis in original).

106. Id. at 135 (emphasis in original). 
But should that increase in present value affect the determination of the amount of cost to be allocated to the exhaustion of the first year of the machine's useful life? Surely not. The cost of the first year's use is completely unrelated to any unrealized appreciation in the value of the right to use the machine in later years.

It should be emphasized that for tax purposes depreciation is a means of allocating a cost that the taxpayer incurred in a prior year. The normal means of allocating cost to an item of property is to determine what amount the owner paid for that item. For example, suppose $J$ purchases a single unimproved lot for $\$ 100,000$ at a time when the front half of the lot has a value of $\$ 75,000$ and the back half has a value of $\$ 25,000$. Eight years later, each half is worth $\$ 95,000$ as a result of some improvements by the city, and $J$ decides to subdivide the lot and sell the back half for $\$ 95,000$. How does $J$ determine his basis in the rear parcel? He allocates his original $\$ 100,000$ cost between the front and rear portions of the lot, according to the respective values of those portions at the time that he purchased the property. ${ }^{107}$ Thus, $J$ had a basis of $\$ 25,000$ in the rear parcel and recognizes a gain of $\$ 70,000$ on the sale.

Similarly, the cost of a depreciable item should be allocated to each year of the asset's use according to the amount paid for that year's use: the amount of income that the taxpayer initially expected the property to produce in that year, discounted to present value as of the date that the taxpayer acquired the property. In Professor Chirelstein's example, the cost to be allocated to the first year of use of the machine is the $\$ 1045$ that $K$ paid for the income stream for that year. Under this analysis, an accelerated depreciation schedule is an accurate allocation of cost, and the straight line method is distortive in that it unduly defers the taxpayer's recovery of his cost.

The thrust of my thesis is that just as realty can be subdivided geographically by metes and bounds, and just as we allocate the taxpayer's basis to each subdivided parcel according to the amount that the taxpayer paid for that parcel, so can realty (and all other properties) be subdivided temporally, and so should we allocate a taxpayer's basis to each subdivided year according to the amount that the taxpayer paid for the right to the property for that year. When a year of an asset's life is used up, depreciation should be allowed in the amount of the taxpayer's basis that is allocated to that year. ${ }^{108}$

107. Treas. Reg. § 1.61-6(a) (1957). See Fairfield Plaza, Inc., 39 T.C. 706 (1963), acq. in result 1963-2 C.B. 4; Wellesley A. Ayling, 32 T.C. 704, 710 (1959), acq. in result 1959-2 C.B. 3.

108. One interesting aspect of the above analysis is the consequence of applying it to the sale of a personal residence or other personally used property. If the above thesis is carried to 
Interestingly, Professor Chirelstein's general discussion of cost recovery includes analysis supporting the thesis that, from an economic viewpoint, accelerated depreciation provides a measurement of net income that is at least as accurate as other methods. In discussing the manner in which the taxpayer should recover the cost of purchasing corporate stock (a nonwasting asset), Professor Chirelstein raises three different possibilities for consideration:

(1) We could treat each dividend as a return of capital until the shareholder's cost is recovered and treat all dividends thereafter as income.

(2) We could treat each dividend as income and allow the shareholder to recover his capital only when the shares are sold.

(3) We could treat each dividend partly as income and partly as a return of the shareholder's capital. We could allocate to capital recovery an amount equal to the present value when the shareholder bought the stock of the dividend that the shareholder estimated he would receive during the year in question; we could treat the balance of the actual dividend as income. ${ }^{109}$

Professor Chirelstein acknowledges that "there is something to be said for each of [the three alternative suggestions], and not very much more to be said for one than for the others." 110 The principal fault that Professor Chirelstein finds with the third alternative is not conceptual but rather rests on the administrative unfeasibility of

its logical conclusion, the taxpayer's basis in his residence should equal only the amount of basis that he has in the remaining useful life of that asset. In the years before he sold the residence, he used up his basis in his right to use the residence during those prior years. There are many practical reasons, including administrative convenience, for exempting personally held property from basis adjustment. The prospect of determining the useful life, salvage value, and depreciation method for each personally used item is mind boggling. The lax law properly makes no provision for basis adjustments in such cases, but the principle is worth noting. Cf. M. Chirelstein, supra note 45, Il 15.02, at 253 (basis adjustment for personal residences would be logical but for several reasons Code does not provide for them).

Another question that flows from the above analysis is whether depreciation deductions should be permitted for income-producing assets that have no ascertainable useful life. For example, the purchase of a share of stock is equivalent to the purchase of the income stream from that share. The value of the stock is equal to the sum of the present values of the anticipated annual income from the stock, and the present value of the income after a substantial length of time (such as 30 years) is so small as to be disregarded. Should the taxpayer deduct the cost of each year's dividend income as depreciation for that year? As Professor Chirelstein points out, a solid case can be made for an allocation of cost. See M. CHIRELSTEIN, supra note 45, I 2.01, at 25-27. See also Joyce \& Del Cotto, The $A B(A B C)$ and BA Transactions: An Economic and Tax Analysis of Reserved and Carved Out Income Interests, 31 TAX. L. REv. 121, 123-30 (1976). Presumably, the most important reasons that the current tax law allows no depreciation are: 1) administrative convenience (the determination of an investor's expected return is highly conjectural, although conventional methods of depreciation could be employed just as they are with other assets); 2) adherence to established accounting practice; and, 3) application of the salvage value principle to a nonwasting asset. This issue is discussed in greater detail in text at notes 116-20 infra.

109. M. Chirelstein, supra note 45, I 2.01 (a), at 25-26.

110. Id. at 26. 
finding an investor's anticipated dividend return. ${ }^{11}$ But the third alternative is the same accelerated form of cost recovery that I recommend for depreciation of a wasting asset. In light of that analysis, it is surprising that Professor Chirelstein describes the decelerated sinking-fund method as the only proper method in principle. ${ }^{112}$

Let us return to the example of $K$ and the machine with the fiveyear useful life to consider the merits and faults of the sinking-fund notion that the exhaustion of an asset should be offset by the unrealized appreciation in its remaining useful life. Suppose $K$ elects to rent a machine for one year. Since he desires a $15 \%$ return on his investment, he pays $\$ 1045$ to rent the machine, and he properly deducts that expense. But, according to the sinking-fund concept, if instead $K$ purchases the machine, the cost of that first year's income is reduced to $\$ 573$ because $K$ will enjoy an unrealized appreciation of $\$ 472$ on the remaining four years' life of the machine. To test that consequence, let us alter the facts slightly.

Suppose $K$ seeks to purchase the machine for $\$ 4000$, but the seller $G$ is not willing to part with the machine right away. The seller offers to sell $K$ the machine, subject to $G$ s right to retain and use it for one year; thus, $G$ offers to sell $K$ a future interest in the machine, to commence in possession one year later. $K$ agrees. Looking at the schedule above, $K$ determines the value of income streams for years Two to Five by discounting the revenue for each year to its present value at the beginning of Year One. The sum of those present values is $\$ 2955$, and $K$ pays $G$ that amount. But $K$ still needs a machine for Year One, so he rents a similar machine from $H$ for one year at a rental of $\$ 1045$. At the end of Year One, $K$ has spent $\$ 1045$ to rent a machine and acquires possession of a like machine, the value of which has risen from the $\$ 2955$ that he paid for it to $\$ 3427$ (the increase in value is caused by the fact that the income stream will be discounted one less year). The unrealized appreciation of the machine that $K$ bought will not affect the amount of his deduction for the rental of the first machine. Nor will $K$ be taxed on that appreciation. Yet, from $K$ 's standpoint, there is little difference between this latter situation and the outright purchase of the machine for $\$ 4000$. In both cases, $K$ pays $\$ 4000$ for the use of the machine for five years. Clearly, given a realization doctrine, a decelerated rate of depreciation does not square with our tax structure. ${ }^{113}$

111. Id. at 27.

112. Id. at 135 .

113. See Joyce \& Del Cotto, supra note 108. One might question whether $K$ would be able to rent the machine at a rental of $\$ 1045$. Since we assumed that a vendor would be willing to 
To take a final illustration, let us reconsider the example of the purchase of fire insurance, but this time discount the premiums to present value. Suppose $E$ wishes to purchase fire insurance for a five-year period, and the current amount of a year's premium is $\$ 1000$. Because $E$ is paying all of the premiums for the policy at the beginning of the first year, the premiums for subsequent years must be discounted. The parties agree upon a $10 \%$ compounded rate of discount.

The premiums are determined as follows:

\begin{tabular}{ccc} 
Year One & $\begin{array}{c}\text { Undiscounted } \\
\text { premium }\end{array}$ & $\begin{array}{c}\text { Discounted } \\
\text { premium }\end{array}$ \\
Year Two & $\$ 1,000$ & $\$ 1,000$ \\
Year Three & 1,000 & 909 \\
Year Four & 1,000 & 826 \\
Year Five & 1,000 & 751 \\
Total & 1,000 & 683 \\
\hline 55,000 & $\$ 4,169$
\end{tabular}

Thus, $E$ paid $\$ 4169$ at the beginning of Year One for fire risk protection for five years. After one year, what amount of $E$ 's cost of $\$ 4169$ should be allocated to that first year as a depreciation deduction? While $E$ paid $\$ 1000$ for that first year's coverage (as indicated in the table above), the value of the remaining four years of coverage has increased because of the reduction by one year of the period of discount. That is, if $E$ were to sell her building and the fire insurance thereon, the value of the remaining four years coverage of fire insurance would be $\$ 3486$ as indicated below:

$\begin{array}{lr} & \text { Value } \\ \text { Year Two } & \$ 1,000 \\ \text { Year Three } & 909 \\ \text { Year Four } & 826 \\ \text { Year Five } & 751 \\ & \text { Total } \$ 3,486\end{array}$

The value of the fire insurance at the beginning of the year was

sell the machine for $\$ 4000$, which represents a price of $\$ 1045$ for the first year's income stream, it does not appear unreasonable to assume that a person in the business of leasing such machines would rent it for one year for the same price (\$1045). In any event, if the lessor required $K$ to pay a larger rental for the machine, that would not alter the significance of the hypothetical example. $K$ would deduct whatever amount of rent he paid in Year One without regard to the fact that the value of the future interest he had purchased in the other machine had increased. 
$\$ 4169$ and the value at the end of the year was $\$ 3486$; so, under the sinking-fund method, only $\$ 683$ of depreciation would be allowable for that year.

If instead; $E$ were to purchase five separate fire insurance policies from five different companies, paying $\$ 1000$ for the policy covering Year One, $\$ 909$ for Year Two, $\$ 826$ for Year Three, $\$ 751$ for Year Four, and $\$ 683$ for Year Five, current tax law would clearly permit her a deduction of $\$ 1000$ after one year. The unrealized appreciation of her four other policies would not affect that deduction. There is no reason to believe that the true economics of the transaction are different where $E$ buys one five-year policy instead of five separate policies. In Section III, we developed a strong case for allocating more cost to the early years of an annuitant's periodic receipts than to the later years; the same analysis is persuasive for depreciation.

In sum, the proper method for allocating the cost or basis of a depreciable asset is to allocate to each year the present value of that year's anticipated income, determined at the date that the taxpayer acquired the asset. Under this method, the amount that the taxpayer actually paid for a year's income is the amount of cost that is allocated to that year. This analysis has assumed that the owner will derive a constant annual amount of income from the use of an asset and has not taken costs for repairs and maintenance into account. In fact, the anticipated annual income from an asset will rarely be a constant figure, but without evidence of the expected income pattern from a particular type of asset, assuming constant income is probably the best one can do. For buildings, however, empirical data suggest that the income from older buildings is less than the income from newer buildings. ${ }^{14}$ A smaller anticipated income stream during the later years of a building than during its earlier years means that a purchaser will pay less for the later years of the income stream. This in turn magnifies the amount of acceleration that is appropriate for proper income measurement.

On the other hand, the purchaser of a new building may well anticipate a smaller income stream for the first one or two years, expecting a higher vacancy rate in those early years. Not all new buildings suffer high vacancy rates, however, and on balance, the current rates of acceleration do not appear to be excessive. Moreover, if the owner incurs greater repairs and maintenance costs in the later years of an asset's use, ${ }^{115}$ they will also reduce the amount of

114. See Taubman \& Rasche, supra note 100 , at $335,337$.

115. But see id. at 336-37 (authors found that repair and maintenance costs for buildings remained fairly constant). 
the purchase price that is allocable to those years - the purchaser will pay less for the anticipated gross income from a year where the costs of producing that gross income are larger.

The necessary conclusion is that an accelerated rate of depreciation provides a more accurate measurement of net income than does a straight line method. The method's greater accuracy does not, however, mean that only accelerated depreciation is proper. Below, I shall discuss several areas in which the tax laws sacrifice accuracy and the realization doctrine to other valid tax policies. Nevertheless this analysis does show that where it reflects the greater cost of the early years of income stream, acceleration of cost recovery is not a "preference." And contrary to the assertion of the champions of the decelerated methods, straight line depreciation surely does not constitute a preference.

The current tax laws include exceptions to the principle of realization that superficially appear to provide modest support for a more general application of the sinking-fund concept. The current tax treatment of salvage value is a good example. As noted above, ${ }^{116}$ the amount to be depreciated equals the difference between the taxpayer's basis in an asset and the asset's salvage value. Salvage value is an estimate made at the time the asset is put into service of the price at which the asset will sell when its useful life is exhausted. ${ }^{117}$ The price at the end of the asset's useful life is equal to the present value at that later time of the estimated income stream to be derived from the property after the useful life has expired. That calculation, by shifting the perspective from the date the asset is put into service to the date the asset exhausts its useful life, is consistent with the sinking-fund theory. From an economic view, however, no such shift in perspective is appropriate, and therefore salvage value should be reduced to present value as of the date the asset is put into service. ${ }^{118}$ While the current tax practice is inaccurate, it quite rea-

116. See text following note 59 supra.

117. Treas. Reg. \& 1.167(a)-1(c) (1956).

118. In this connection, note that in their basic text on economics, Professors Alchian and Allen state that in determining the cost of operating an asset for a stated period of time, the value of the asset at the end of that period, discounted to present value as of the beginning date of the period, is subtracted from the value of the asset at the beginning of the period. See M. ALCHIAN \& W. ALLEN, supra note 54, at 247-48. The authors stress that the two figures "must be compared in contemporaneous values" in order to determine the cost accurately.

A contrary view was expressed by Professor Eisner, who maintained that in determining depreciation, the loss in value of an asset should be offset by any "increases in the value of the property." Eisner, supra note 100. Indeed, Professor Eisner was sufficiently convinced that depreciation allowances are excessive to recommend to Congress that serious consideration be given to eliminating the allowance for depreciation deductions entirely. Id. Eisner would have been justified in believing that he was the first person to propose such radical action, but 
sonably promotes simplicity and ease of administration. It is difficult enough to require a taxpayer to speculate about the price at which an asset will sell some years in the future without demanding that he then reduce the estimated price to present value. An estimate of selling price is not likely to be sufficiently reliable to justify the fine tuning of reducing it to present value.

My analysis of the proper way to allocate cost recovery would also seem at odds with the present tax treatment of revenue received on an investment in perpetuity. Under current tax practice, if $P$ pays $\$ 100$ for an annuity of $\$ 10$ per year forever, each $\$ 10$ payment will be treated as income to $P$, as would a dividend on a share of stock. But why shouldn't $P$ be treated as having purchased an income stream of $\$ 10$ per year and the discounted cost of his right to each year's payment be allocated to the actual payment for such a year? ${ }^{119}$ At a $6 \%$ discount rate, $P$ paid $\$ 9.43$ for the right to the first year's $\$ 10$ payment, $\$ 8.90$ for the right to the second year's payment, etc. The cost of the right to payments many years in the future would be so small as to be disregarded, but under this allocation only $57 \$$ of the first year's $\$ 10$ payment would be income. This treatment clearly follows from my earlier analysis of allocation of cost recovery, yet the tax laws presently treat every bit of each $\$ 10$ payment as income to $P$. Why?

One possible explanation for that treatment would be a congressional endorsement of the so-called sinking-fund depreciation concept. Under this theory, Congress might have decided that the cost recovery component of each $\$ 10$ payment should be offset by an exactly equal amount of appreciation in the value of the right to the remaining income stream, since the realization of the future payments is one year closer. Yet the sinking-fund rationale has never been articulated as the reason for allowing no cost recovery, and while it seems impossible to prove the true reason for the present treatment, I believe quite different considerations motivated it.

I have remarked that under the present tax laws, salvage value is the estimated price for which the owner can sell an asset at the expiration of its useful life, and this estimated price is not discounted to present value at the time of purchase. That treatment of salvage value is a compromise with the principle of realization, but it is a

surprisingly the eradication of depreciation deductions was proposed on at least one prior occasion. In 1935, Representative Marcantonio unsuccessfully sought to have included in a revenue bill a provision to eliminate the depreciation deduction. 79 CONG. REC. 12,426 (1935).

119. See M. Chirelstein, supra note 45, I 2.01, at 25-27; Joyce \& Del Cotto, supra note 108 , at $121,123-30$. 
compromise I think well founded in considerations of simplicity and economy. The treatment of all payments on investments in perpetuity as pure interest can be understood as a simple application of the salvage value limitation. As long as the tax laws do not discount salvage to present value, a nonwasting asset's salvage value will equal its purchase price, and no cost recovery should be allowed. Given the present salvage value rules, the current treatment of the return from nonwasting assets is necessary for consistent treatment of wasting and nonwasting investments.

For depreciation of wasting assets, Congress has imposed the salvage value limitation, but it has also authorized the amortization of the depreciable balance by accelerated forms of depreciation. As we have seen, those accelerated forms are more consistent with the general doctrine of realization than is the tax treatment of salvage value and nonwasting assets. I see no benefit in labeling a congressional value judgment a "tax expenditure" when it is consonant with essential principles of our tax system.

A number of consequences flow from the conclusion that accelerated depreciation is more accurate (or at least no less accurate) than other methods. First, any proposal to eliminate accelerated depreciation should offer significant justifications and should not rest on a general belief that acceleration is inaccurate. Second, the current limitations on the availability of accelerated depreciation for realty should be reexamined. Third, accelerated depreciation on buildings should be eliminated from the Tax Expenditure Budgets: whether or not methods such as $200 \%$ declining balance offer more depreciation than I have justified here, the present Budgets clearly exaggerate the true amount. And once it is known that some acceleration of depreciation is proper, it becomes extremely difficult to measure the anticipated income stream from buildings with sufficient accuracy to determine precisely the appropriate amount of acceleration. It would be misleading to pluck a dollar figure from conjecture and record it as the preference involved. Fourth, Congress should probably repeal the inclusion of the accelerated portion of depreciation on buildings and on certain other properties as a tax preference item under sections $57(a)(2)$ and (3) that, inter alia, ${ }^{120}$ may be subject to the surtax known as the "add-on minimum tax." Fifth, Congress should repeal the provision in section $312(\mathrm{k})$ preventing corporations from reducing their earnings and profits by the accelerated portion of depreciation. Sixth, the conceptual justifications for the recapture

120. For example, inclusion in $\S \S 57(a)(2)$-(3) may affect the amount of income that qualifies for the 50\% maximum tax on personal service income. I.R.C. $§ 1348$. 
of depreciation provisions become suspect. In the next Section, I examine those rules in detail.

\section{RECAPTURE OF DEPRECIATION}

\section{A. Background}

As part of the Revenue Act of 1962, Congress adopted section 1245 - the recapture of depreciation provision. ${ }^{121}$ In essence, this provision requires that the taxpayer recognize the gain realized on disposing of most depreciable personalty (and of certain depreciable realty other than a building or its structural components) as ordinary income to the extent that the gain arises as a consequence of depreciation previously allowed to the taxpayer. The provision effectively treats as ordinary income any of the taxpayer's gain that he would not have realized but for the previous allowance of a depreciation deduction. Section 1245 applies to all dispositions of covered property unless the transaction is exempt under the terms of section 1245 itself; it overrides other Code sections and can cause recognition of income even though another provision expressly grants nonrecognition. For convenience, I will ignore the limited types of realty that section 1245 covers, and I will treat the section as applying only to personalty, both tangible and intangible. All depreciation and amortization deductions taken on personalty are subject to recapture, regardless of the method of depreciation employed. Thus, even straight line depreciation is subject to recapture.

Before the adoption of the 1962 Act, a gain or loss recognized on the sale or exchange of depreciable property that had been used in a trade or business for a significant period of time was characterized as gain or loss under section 1231. Congress first adopted section 1231 in 1942 as a response to problems that arose after the outbreak of the Second World War. ${ }^{122}$ Although it is an oversimplification, for our purposes it is sufficient to state that gains recognized on a sale or exchange under section 1231 are generally treated as long-term capital gains, and losses recognized on a sale or exchange under section 1231 are treated as ordinary losses. A few tax specialists believe that Congress erred in providing capital gains treatment for such properties under section 1231, preferring that any gain arising from the conduct of a business be treated as ordinary income. ${ }^{123}$ Presumably

121. See Revenue Act of 1962, Pub. L. No. 87-834, § 13(a)(1), 76 Stat. 960.

122. See W. ANDREws, supra note 100 , at 482 ; B. BitTKER \& L. STONE, FEDERAL INCOME, ESTATE AND GIFT TAXATION 578-79 (4th ed. 1972).

123. See $1 \mathrm{~S}$. Surrey, W. Warren, P. McDaniel \& H. Ault, Federal Income TaXaTION 1018 (1972 ed.). 
because it was unable to convince Congress to repeal section 1231, the Treasury Department proposed a recapture of depreciation provision that carves out from section 1231 much of the gain from depreciable personalty that otherwise would have been treated as a long-term capital gain. The recapture of depreciation provisions can be viewed as effectively repealing part of section 1231 .

Whether Congress should repeal section 1231 is a question that will not be examined in this Article. I believe that Congress should retain section 1231,124 but I leave that issue for another article. I will limit myself here to a consideration of the validity of the justifications Congress accepted in adopting the recapture provisions.

In his statement at the Senate Finance Committee's Hearings on the Revenue Act of 1962, the Secretary of the Treasury, Douglas Dillon, stated:

The President recommended that capital gain treatment be withdrawn from gains on the disposition of depreciable property, both real and personal, to the extent of prior depreciation allowances.

Such gain reflects depreciation allowances in excess of the actual decline in value of the asset and under the President's proposal would be treated as ordinary income. Any gain in excess of the cost of the asset would still be treated as capital gain. This reform would eliminate an unfair tax advantage which the law today gives to those who depreciate property at a rate in excess of the actual decline in market value and then proceed to sell the property, thus, in effect, converting ordinary income into a capital gain. It is particularly essential at this time in view of the impending administrative revision of depreciation guidelines. ${ }^{125}$

To paraphrase the Treasury Department argument, a taxpayer deducts depreciation from ordinary income; when he sells the depreciated asset, any "excessive" depreciation that he recaptures may get long-term capital treatment under section 1231 . In that manner, the taxpayer can convert what would be ordinary income into a longterm capital gain. At least regarding personal property, Congress was convinced by that argument ${ }^{126}$ and adopted section 1245 .

Congress was making other Code revisions when it adopted section 1245, and the pressures that surrounded those other changes shed light on the origins of the recapture provision. One set of changes was designed to allow more flexibility in estimating depreciation. As Professor Samuelson notes in his basic text on economics,

124. See M. Chirelstein, supra note 45 , I 10.02, at 309-10.

125. Revenue Act of 1962: Hearings on H.R. 10650 Before the Senate Comm. on Finance, 87th Cong., 2d Sess. 87-88 (1962).

126. H.R. REP. No. 1447, 87th Cong., 2d Sess. 66-68 (1962), reprinted in 1962-1963 C.B. $405,470-72$. 
"Although depreciation is usually figured by some apparently exact formula, every accountant knows that the estimates are really very rough, being subject to large and unpredictable errors and involving arbitrary corrections and assumptions." 127 Given that imprecision, it is understandable that the depreciation provisions before 1962 had been the source of many heated disputes between taxpayers and the Service. To minimize such disputes and the bad will they generate, Congress adopted a number of liberalizing provisions, including section 167(f), which authorized a taxpayer to reduce the salvage value of certain personal property items by up to $10 \%$ of the asset's basis. Congress felt more comfortable liberalizing the depreciation allowance in that manner when it knew it could recapture "excessive" depreciation with section 1245.128

The 1962 legislation did not extend the recapture of depreciation rules to buildings or to most other depreciable realty. The refusal to do so was later explained as resting on the fear that much of the gain in realty is a product of appreciation through external market conditions rather than a consequence of excessive depreciation claims by the taxpayer. ${ }^{129}$ In 1964, however, Congress reduced the discrepancy between its treatments of realty and personalty by adopting the first version of section 1250. Section 1250 does not recapture depreciation with quite the same vigor as section 1245. Under section 1250, if the taxpayer has held the realty for more than one year, only the socalled "additional depreciation" is subject to recapture. The "additional depreciation" is the difference between the aggregate depreciation allowed to the taxpayer before the time of disposition and the aggregate depreciation that would have been allowable to the taxpayer over the same period under the straight line method of depreciation. ${ }^{130}$ The committee reports to the 1964 Act explain the reasons that Congress imposed restrictions on the recapture for realty:

Your committee generally has limited the depreciation recapture to the excess over straight line depreciation because it believes that only to this extent could the depreciation taken appropriately be considered in excess of the decline in the value of the property which occurs over time. If a gain still occurs, it is believed that this is attributable to a rise in price levels generally rather than to an absence of a decline in the value of the property. The portion representing the rise in value is

127. P. Samuelson, Economics 124 (10th ed. 1976).

128. H.R. REP. No. 1447, supra note 126, at 66-68.

129. S. REP. No. 830, 88th Cong., 2d Sess. 132 (1964); H.R. REP. No. 749, 88th Cong., 1st Sess. 101-02 (1963).

130. I.R.C. $\S 1250(b)$ 
comparable to other forms of gains which quite generally are treated as capital gains. Moreover, your committee believes that when the property is held for an extended period of time, gains realized on the sale or other disposition of the property are more likely to be attributable to price rises generally than to an excess of depreciation deductions. For that reason, your committee's bill also tapers off over a 10-year period the proportion of the additional depreciation (or gain where smaller) which is to be treated as ordinary income upon the sale of the property. ${ }^{131}$

As originally adopted, section 1250 phased out recapture by $1 \%$ for each month that the property was held in excess of 20 months. Thus, if the taxpayer held the realty for at least 10 years, no depreciation would be recaptured. Subsequent legislation eliminated this phase-out provision; currently the Code reduces the amount of additional depreciation to be recaptured only for owners of certain low income housing projects.

In sum, the entire amount of depreciation allowed on personal property is currently subject to recapture. For buildings held more than one year, only the additional amount of depreciation above straight line depreciation is subject to recapture.

\section{B. Is Recapture Justifiable?}

Congress rested its adoption of the recapture rules on two linked assumptions: (1) that true depreciation for a year is the amount of decline in the asset's value during the year, and therefore (2) that a taxpayer who disposed of a depreciable asset when its value exceeds its basis probably claimed excessive depreciation during the preceding years. ${ }^{132}$ Yet those initial assumptions are misguided. As we saw in Section IV, selling an asset for profit does not indicate that an excessive amount of depreciation was allowed. Quite apart from any change in market prices, the selling price of an item will be greater than its original cost less a "true" amount of depreciation, because of the appreciation that will have occurred in the discounted value of the property's remaining income stream. More fundamentally, Congress erroneously assumed that "accurate" depreciation is equal to the decline in value of an asset over a period of time. But as I demonstrated in Section IV, the accurate depreciation for an asset

131. S. Rep. No. 830, 88th Cong., 2d Sess. 133 (1964); H.R. Rep. No. 749, 88th Cong., 1st Sess. 102-03 (1963).

132. Congress did not believe that a gradual increase in market value of the remaining life of a depreciable asset should cause recapture, since such an increase does not indicate that an excessive amount of depreciation had been claimed. Because Congress determined that market value is more likely to rise for realty, it provided a more limited form of recapture for buildings. See note 131 supra and accompanying text. 
for a given year is the cost to the taxpayer of that year's use; the taxpayer's basis should be allocated among the temporal divisions of the asset's useful life, and the amount of basis allocated to a given year is the amount that should be allowed as depreciation for that year.

To illustrate, let us reconsider the example of $K$ and the machine with a five-year useful life. $K$ expected the machine to produce income of $\$ 1200$ per year for the five-year period. Discounting at a little more than a $15 \%$ rate, the present values of the income stream from the machine, determined at Year One, are as follows:

$\begin{array}{lr}\text { Year One } & \$ 1,045 \\ \text { Year Two } & 905 \\ \text { Year Three } & 790 \\ \text { Year Four } & 687 \\ \text { Year Five } & 573 \\ & \text { Total } \$ 4,000\end{array}$

The value of the machine at the time that $K$ purchased it was $\$ 4000$ (the sum of the present values of the income stream), and $K$ paid that amount. $K$ elected to depreciate the machine on the straight line method. Accordingly, $K$ claimed and was allowed a depreciation deduction of $\$ 800$ for Year One and an additional depreciation deduction for Year Two. At the beginning of Year Three, $K$ sold the machine. The income stream of the machine continued to be $\$ 1200$ per year, so the value of the machine at the beginning of Year Three was $\$ 2740$ - the sum of the present values of the income stream for a three-year period ( $\$ 1045$ plus $\$ 905$ plus $\$ 790$ ) and $K$ sold it for that amount. $K$ 's basis in the machine at that time was equal to the difference between his cost of $\$ 4000$ and the $\$ 1600$ of depreciation that he took in Years One and Two: $\$ 2400$. When he sold the machine for $\$ 2740, K$ recognized a gain of $\$ 340$ on the sale, all of which is characterized as ordinary income by section 1245 .

Was $K$ not allowed an excessive amount of depreciation? The $\$ 1600$ of depreciation allowed to him is $\$ 350$ less than the $\$ 1950$ he actually paid for those two years' use ( $\$ 1045$ for Year One plus $\$ 905$ for Year Two). The $\$ 340$ gain that $K$ recognized is clearly attributable to the increase in value of the remaining three years of useful life of the machine, an increase caused by the reduction of the time before the right to those future years of use becomes a present possessory right to produce income. The ordinary income imposed by section 1245 on $K$ is erroneously labeled as a recapture of $K$ 's depreciation. Instead, it is an exception to section 1231 treatment that is 
imposed on the appreciation of the remaining useful life of a depreciable asset.

If, because of inflation or other market factors, the income stream from the machine increased above $\$ 1200$ per year, then the value of the machine in Year Three would have been greater and section 1245 would have forced $K$ to recognize more ordinary income. Such market price fluctuation is the essence of a capital gain and should not be converted to ordinary income merely because the owner of the asset had previously used the asset and deducted the associated basis. Whether capital gains treatment should be granted at all is a separate question. My theses here are only that the ordinary income treatment imposed by section 1245 is inconsistent with our current capital gains system, and that the misleading slogan "recapture of depreciation" may have induced Congress to adopt an exception to capital gains treatment without appreciating how little "recapture" of excessive depreciation was really involved.

I do not contend that straight line depreciation will never cause an excessive allowance: if the asset's useful life or salvage value is understated, the taxpayer will deduct more than a fair allocation of basis, and such understatement can occur for a variety of reasons. The estimates made of useful life and salvage value are very inexact guesses, ${ }^{133}$ and statutory provisions permit the use of shorter useful lives for some assets (the ADR election) and a reduction of salvage value for certain tangible personalty. ${ }^{134}$

Yet I do contend that the recapture provisions of section 1245 are an unnecessarily drastic response to the possibility of excessive depreciation. As we have seen, the gain recognized on a sale bears no logical relation to the amount of excessive depreciation. Some gain is appropriate because of the increase in value of the remaining life of an asset that accompanies the passage of time. In our current economy, much of the gain will be attributable to inflation if the owner has held the asset for more than a few years. To tax inflationary gain at all is very close to a tax on capital, and to tax it at ordinary income rates is especially harsh. Perhaps one of the principal justifications for capital gain treatment is to reduce the tax rate on inflationary gains, and the recapture rules contravene that policy. By relying on the gain recognized at a sale, the recapture provisions are far more likely to be taxing appreciation over time, inflation, and other market gains than to be recapturing excessive depreciation.

133. See text at note 127 supra.

134. I.R.C. \& 167(f). 
Even the excessive depreciation allowed by ADR or salvage value reduction will not be too significant for a taxpayer using the straight line method, since, as we have seen, some acceleration is appropriate. Admittedly, a taxpayer can combine those two elections with an accelerated depreciation method to magnify the amount of acceleration excessively. Nonetheless, cause for concern lies only where the taxpayer uses an accelerated depreciation method, and no straight line depreciation should be recaptured.

Congress should either repeal or amend the recapture provisions of section 1245 to recapture no more than the "additional depreciation" described in section 1250 - the excess of the aggregate depreciation allowed over the aggregate amount allowable under the straight line method. In some cases, such a recapture rule will impose ordinary income on market price gains and in some cases the rule will not recapture all of an excessive depreciation allowance, but it is a feasible rule to administer and provides a less inaccurate measurement than the current version of section 1245. Moreover, for the reasons I discuss below regarding section 1250, even the additional depreciation amount subject to recapture should be reduced with the passage of time.

Congress should also modify or repeal section 1250. If an "accurate" measurement of depreciation were used so that the present value of the right to a year's income were allocated to that year, the longer the taxpayer held an asset, the greater the gain that he will recognize. This is so because the taxpayer's basis in the later years of use of a building is quite low compared to his basis in the earlier years, and the value of those later years will increase substantially as the present right to those later years approaches. Consequently, the gain recognized in a sale after many years is far less likely to represent excessive depreciation than is a gain on a sale after a brief holding period. Accordingly, the additional depreciation that is subject to recapture should be reduced by some percentage for each month that the asset is held after a specified period of time. The percentage of reduction and the period of holding could be determined by examining a number of examples where market conditions are held constant and property is sold for the present value of the remaining income stream. The effect of inflation on the real estate market has been dramatic and gives special impetus for a revision or repeal of section 1250 .

The facts of building ownership cast even more doubt on the wisdom of section 1250. The actual life of the shell of a building typically is quite a bit longer than the useful life employed in depre- 
ciating it. ${ }^{135}$ However, the internal portions of a building last for a considerably shorter period, and the useful life that is employed seeks to weigh the life of both the shell and the internal portion. ${ }^{136}$ Furthermore, a longer useful life for the buildings would have little effect on the proper amount of depreciation that is allowable. The present value of the income from property more than 40 years after its purchase, for example, would be so small as to justify disregarding it. By way of illustration, the value of $\$ 1$, discounted at a $12 \%$ rate, 30 years in the future is a little more than $3 \$$; the value of a dollar 40 years in the future is only $1 \$$; and a right to receive a dollar 50 years in the future is worth substantially less than $0.5 \$$. The length of time employed as the useful life of a building is not likely to distort depreciation to any significant extent.

Moreover, since the annual income from a building declines as the building ages, ${ }^{137}$ the amount of the purchase price paid for the anticipated income from the later years of a building's use will be smaller than the amount paid for the earlier years, and the amount attributable to the later years will be even further reduced if the purchaser anticipated greater repair and maintenance costs in those later years. ${ }^{138}$ When this reduction of anticipated income is included in the computation of the present value of the anticipated income for years after some 30 or 40 years of use, it renders the current value of those later years even more insignificant than indicated above. The amount of purchase price for those later years can be disregarded as de minimis.

There is even less justification for recapturing depreciation on buildings than there is for recapturing depreciation of personalty. The salvage value reduction provision of section $167(\mathrm{f})$ does not apply to the depreciation of buildings. The ADR election is not available for buildings placed into service after 1973.139 Consequently, the only acceleration available for the depreciation of buildings is through the method of depreciation employed. Under current law, taxpayers can depreciate only new residential rental property at any significantly accelerated rate. Unless Congress liberalizes the availability of acceleration, there is little reason to recapture any deprecia-

135. Taubman \& Rasche, supra note 100 , at 334,337 n.12.

136. Id.

137. See text at note 114 supra.

138. It should be noted, however, that at least one study indicates that repair and maintenance costs are not greater for older buildings. See Taubman \& Rasche, supra note 100 , at 336.

139. Rev. Proc. 77-3, 1977-1 C.B. 535. 
tion on buildings other than, perhaps, new residential rental property. Even there, a substantial amount of acceleration is proper because the greatest cost should be allocated to the early years of rental use, ${ }^{140}$ and it is therefore doubtful whether any recapture is justified, especially if the additional depreciation was previously subjected to the minimum tax on tax preference items.

Before moving to the next topic, some consideration should be given to whether, even assuming that the amount taxable as ordinary income under the recapture rules is totally unrelated to whether the taxpayer took an excessive amount of depreciation, the recapture rules are nevertheless justifiable on other grounds. In other words, even though the stated reason for adopting the recapture rules proves to be fallacious, it is possible that there is a different and convincing rationale for the ordinary income treatment imposed by sections 1245 and 1250. The principal alternative ground for justifying recapture appears to be the contention that the recognition of a gain should be characterized as ordinary income to the extent that the gain is attributable to appreciation that occurs solely as a consequence of the passage of time. In the instant context, this contention would treat the appreciation in value of the future income stream of a depreciable asset as either interest income or as sufficiently akin to interest to warrant its being treated the same as interest for income tax purposes. The proponents of this view would therefore allocate the gain on the sale of a depreciable asset into two parts: the "interest-type" appreciation that occurs because of the proximity of the realization of the future income stream, and the gain or loss because of external market conditions. For the reasons explained below, no such allocation is justifiable. Before considering the merits of this "interest-type" characterization, let us first examine Jones v. Commissioner, ${ }^{141}$ the principal judicial support for the allocation approach.

In Jones, the taxpayer had purchased a contingent remainder interest in a trust. After the death of the life-income beneficiary, the taxpayer's remainder vested, and his portion of the trust corpus became distributable to him. If the taxpayer had continued to hold his remainder interest and collected the trust corpus distribution, he would have recognized ordinary income in an amount equal to the difference between the corpus distributed to him and his basis in the

140. As previously noted, the anticipated income stream for the first one or two years of a new building may be less than for later years because of the possibility of a higher vacancy rate. See text following note 114 supra. If empirical data demonstrates that that is commonly so, there is justification for recapturing depreciation for a new building that taxpayers hold for only a short period of time (such as one year) before disposing of it.

141. 330 F.2d 302 (3d Cir. 1964). 
remainder interest. The reason that his gain would have been ordinary income is that the distribution would not qualify as a "sale or exchange" under section 1222. For the explicit purpose of avoiding ordinary income treatment, the taxpayer sold his vested remainder interest to a friend shortly before the trustee distributed the corpus. The taxpayer then claimed that his gain on the sale was a long-term capital gain.

In its first decision, ${ }^{142}$ the Tax Court characterized the taxpayer's gain as ordinary income under the anticipation of income doctrine. On appeal, the Third Circuit reversed. ${ }^{143}$ However, the Third Circuit held that the discount that Jones received when he originally purchased the remainder interest could be measured according to the life expectancy of the life income beneficiary, and the gain that the taxpayer recognized on the sale of the remainder interest was ordinary income to the extent that it constituted a realization of that discount income. The balance of the taxpayer's gain was a capital gain. The Third Circuit remanded the case to the Tax Court to allocate the taxpayer's receipts on the sale of the remainder interest between the ordinary income component and the capital gain component.

On remand, the Tax Court noted that any appreciation in the value of the taxpayer's remainder interest was not "interest," which refers to an unqualified obligation to pay a definite sum for the use of money, ${ }^{144}$ but deemed itself bound by the Third Circuit's characterization of part of the increase in value of the taxpayer's remainder as interest income. Accordingly, it allocated 6\% of Jones's purchase price to income each year, compounded annually up to the date of sale.

The Jones decision is an unfortunate promulgation of bad law to mitigate the tax benefit that the taxpayer obtained by selling his remainder interest and transmuting what would otherwise have been ordinary income into capital gain. The Third Circuit apparently was troubled by the fact that a sale made shortly prior to realization can convert income that otherwise would be characterized as ordinary into a capital gain. ${ }^{145}$ The partial "cure" adopted by the Third Circuit is not supportable either by precedent or by tax policy.

The reasons for treating certain types of income as capital and other types as ordinary are diverse and are beyond the scope of this Article. It is worth noting, however, that a likely reason for treating

142. Donald B. Jones, 40 T.C. 249 (1963).

143. 330 F.2d 302 (3d Cir. 1964).

144. Donald J. Jones, MEMo T.C. (P-H) I] 66, 136.

145. See, e.g., Conrad N. Hilton, 13 T.C. 623 (1949). 
interest income as ordinary is that it is a current return on an "investment" (i.e., a loan of money) and is no different from any other current return on an investment. In general, a capital gain applies only to the proceeds derived from the termination of an investment where the value of the investment has increased above the taxpayer's cost. To the extent that the gain realized on a sale is attributable to the recognition of current income that the taxpayer previously earned but had not recognized because of his accounting method, there may well be a case for characterizing the gain as ordinary. But, that is not the case with the remainder interest in a trust, nor is it the case with the gradual appreciation of the right to a future income stream. Current income is an amount payable from a specific person or persons to the taxpayer (such as is the case with the "interest" element in an annuity). In the future income stream situation, there is no person who owes income to the taxpayer. The value of the taxpayer's asset increases because the income potential of the asset is more valuable - the asset produces the same amount of income, but the income has greater value to the owner of the property because of its proximity. There is no obvious reason why the realization of the appreciation in value of an asset should be characterized one way when it arises steadily and predictably, but another way when it occurs erratically and unpredictably. In either event, it is gain from the appreciation in value of an asset rather than the recognition of current income that had been deferred because of the taxpayer's accounting method. The following example may be useful.

Suppose $M, N$, and $O$ form a corporation to investigate whether uranium is located on an area of land and to mine any uranium that is discovered. One and one-half years later, the corporation discovers uranium on its land. This discovery causes a substantial increase in the value of the corporation's stock. The corporation will not be able to mine the uranium for an additional year because of preparations that are necessary. Eight months after the discovery, $M$ sells his stock in the corporation at a gain. The value of $M$ s stock rose because:

(1) The time period for realizing income from the mine became shorter while $M$ held the stock, and thus the present value of the anticipated income from the mine rose (this increase took place both before and after the discovery of the uranium, although the increase was more speculative before the uranium was discovered);

(2) The corporation discovered that uranium was there to be mined. It would hardly seem reasonable to divide $M$ s gain into an ordinary income and a capital gain component, and, contrary to the Jones decision, no such division is made. 


\section{TAX EXPENDITURE Budgets}

The principal thesis of this Article only incidentally touches on the issue of the desirability of the Tax Expenditure Budget concept. The concept is so important and of such scope that it warrants the extensive treatment that it has received in the many works that have already been written on that subject. Much more will be written on this subject in the future, and I hope to participate in the continuing debate. At a later date, I plan to write one or more articles discussing the propriety of the Budget, the uses to which it has been put, and the inclusion of many of the items listed therein. Until that time, a few comments may not be inappropriate.

It is desirable to reexamine the tax laws on a regular basis and to determine what adjustments should be made in light of new tax policies. To the extent that the tax expenditure concept seeks to regularize such reexaminations, it has a laudatory goal. But by designating certain items as "expenditures," the Budgets crystallize the view that those items are not proper measurements of income and deter further inquiries into whether they do indeed conform with tax policies. Part of the genius of the common law is that many judicial holdings are justified by a purpose that wilts under scrutiny but nevertheless prove to be good rules for entirely different reasons. Judges reach results that typically are far better than the rationales they offer. Concededly, the legislative process is quite different from the judicial process. But a legislator's vote to adopt and retain a tax provision may well rest on an intrinsic albeit unarticulated belief that the provision is appropriate for measuring taxable income. It is understandable that the committee reports would stress the benefits to a deserving group rather than wrestle with technical income tax policy concepts. The extent to which a legislator who voted for a medical expense or theft deduction believed that he was providing relief to a person in need and the extent to which he believed that such deductions were proper to measure the actual ability of such a victim to bear a share of governmental costs is highly speculative. Such an inquiry is also not very useful. What is useful is to determine whether such items are proper measures of net income, regardless of the reasons originally given for them.

If it were beyond question that the items included in the Budgets are tax preferences, those objections might be too academic. But, in my opinion, whether many of the items listed in the Budget are properly classified as preferences or subsidies is open to serious question. Our system should encourage exploration of serious issues. 
The inclusion of an item in the Budget tends to squelch such inquiries.

In this regard, it is worth noting just a few of the items that have been listed as tax expenditures. The surtax exemption for corporations previously provided by the corporate tax law was listed as a tax expenditure. One might have regarded that exemption as simply a part of the tax rate structure, but it was included in the Budget as an expenditure because the amount of the exemption was so small in comparison to corporate income that the exemption appears to have been intended to serve as relief for small companies. The Revenue Act of 1978 dispensed with the surtax exemption and instead adopted a five-tier corporate tax rate under which the corporation's first $\$ 100,000$ of taxable income is taxed at rates lower than the maximum $46 \%$ rate. The Tax Expenditure Budgets have divided over whether the lower corporate tax rates constitute a tax expenditure, but Professors Surrey and McDaniel believe that the lower rates should be so classified. ${ }^{146}$ They rely, in part, on the fact that the committee reports to the 1978 Act stressed the "small business" thrust of the lower rates. ${ }^{147}$

The subjectivity of the determination of items to be included in the Budget is troublesome. If there are statements in the legislative history to the adoption of a tax provision that some of its proponents urge its adoption in order to provide assistance to some group, then that is taken as strong (or perhaps conclusive) evidence that the tax provision is a subsidy. ${ }^{148}$ Legislative histories are not sufficiently reliable indicators of legislative purpose to justify using them for the purpose of expenditure classification. If an item is a proper factor in measuring net income, it should not become a tax preference merely because some members of Congress either viewed it that way or described it that way to make what they thought to be the strongest political case for its adoption. Some members of Congress may well be more concerned about the effect of proposed legislation on their constituents than about the niceties of the proper measurement of net income.

Some other questionable items that are included in the Budgets are casualty loss deductions, medical expense and theft loss deductions, and the exclusion of an employer's contribution to an employee's medical insurance premiums or medical care expenses.

146. Surrey \& McDaniel, supra note 8, at 225, 234-35.

147. Id. at 234-35.

148. Id. at $228,234-35$. 
Until Congress repealed the percentage standard deduction, the Budgets classified the excess of the percentage standard deduction over the minimum standard deduction as an expenditure. Perhaps the inclusion of such items was proper, but surely there are reasonable justifications for those items that do not rest on tax subsidy notions, and their inclusion in the Budgets is open to question.

In their excellent recent article, Professors Surrey and McDaniel note that tax expenditure analysis does not point either to indexing various transactions for inflation adjustments or to not doing so. ${ }^{149}$ They maintain, however, that if Congress adopted indexing for measuring the gain or loss on the sale of an asset and for purposes of computing depreciation, it would be a tax expenditure unless Congress also adopted indexing for all other types of transactions, such as loans, which are affected by inflation. ${ }^{150}$ In other words, nonindexing is the norm, so indexing only one or two items would be a tax preference. But if Congress adopted indexing for measuring gain or loss and for measuring depreciation, would that not make indexing the norm, so that the failure to provide for indexing elsewhere (such as loans) would be a tax preference or tax penalty (depending upon whether the taxpayer is the lender or the borrower) in those other areas? It is not clear how one determines which provision represents the norm and which represents the variance.

The Tax Expenditure concept is extremely important, and much remains to be explored on that subject. The fact that an examination of accelerated depreciation shows that it is not a tax preference demonstrates the need for scrutinizing each item of a Tax Expenditure Budget and not blindly accepting that it is a variance from the income tax norms.

As a final note, I believe that the Tax Expenditure Budget promotes a philosophy of taxation that, although unstated, is enjoying increasingly widespread acceptance. When the income tax system was first proposed, the opponents objected to the government's taking from its citizens the income that they had earned and which therefore was assumed to belong to them. The Tax Expenditure Budget turns that objection upside down by treating a taxpayer's income virtually as government property, so that any portion of a taxpayer's earnings that the government deigns to permit him to retain is characterized as a "subsidy" to him. This, of course, overstates the actual provisions of the Budget, but by using the term

149. Id. at $280-81$.

150. $I d$. 
"Tax Expenditures," the subtle connotation of government's entitlement to all income is planted. This connotation has been noted by others, but it is vigorously disputed by Professors Surrey and McDaniel. ${ }^{151}$

The Tax Expenditure Budget purports to list government subsidies that are made by failing to capture income that properly should belong to the government rather than to the person who earned it. This concept has spawned muckraking literature, antagonistic to the current tax system, which has labeled our current system a "tax subsidy for the rich" and an "upside-down welfare system."152 In my view, there is a significant difference between taking income from $A$ and giving it to $B$ (a subsidy for $B$ ) and leaving the income that $A$ earned with him (which does not appear to be a subsidy, however unwise it might be as government policy). In addition to other (previously mentioned) failings, the Budget concept has contributed to the erosion of the concept of private ownership of one's earnings. In our complex society, some redistribution of wealth may be desirable policy; but in planning a tax system, the presumption should favor permitting a person to retain his earnings to the extent that it is feasible, and perhaps a healthy skepticism is appropriate for a concept that suggests a contrary presumption. I do believe that tax provisions should be reexamined from time to time and that the tax policies for retaining or altering them should be resolved, ${ }^{153}$ but the quality of such a reexamination is more hindered than aided by labeling some provisions as expenditures and subsidies.

\section{CONCLUSION}

The annual depreciation allowance for an asset should not rest on the decline in value of the asset over that year. Rather, depreciation should reflect the amount the taxpayer expends for the use of the asset during that year. An allocation of the actual cost is at least a proper method of depreciation, and, in my view, is a more accurate measurement of net income than straight line depreciation. Because accelerated depreciation is an accurate and appropriate method of allocating cost, a number of current tax laws and prac-

151. Id. at 231-32.

152. See, e.g., S. Stern, The RAPe of the TAXPayer 5-8 (1973).

153. For an interesting proposal on how one might use the Tax Expenditure Budget for this purpose, see McIntyre, supra note 25. 
tices, including the recapture of depreciation provisions and the Tax Expenditure Budget items for depreciation, should be eliminated or revised. 